\title{
IP in a World Without Scarcity ${ }^{1}$
}

\author{
Mark A. Lemley ${ }^{2}$
}

Economics is based on scarcity. Things are valuable because they are scarce. The more abundant they become, they cheaper they become. But a series of technological changes is underway that promises to end scarcity as we know it for a wide variety of goods. The Internet is the most obvious example, because the change there is furthest along. The Internet has reduced the cost of production and distribution of informational content effectively to zero. In many cases it has also dramatically reduced the cost of producing that content. And it has changed the way in which information is distributed, separating the creators of content from the distributors. On the Internet today, a variety of intermediaries transmit information for free or at a very low cost. Those intermediaries are agnostic about (and quite often ignorant of) the content they are distributing. So the Internet has not only slashed the cost of creation, production and distribution; it has also disaggregated creation and distribution. I can create without distributing, secure in the knowledge that my works will be disseminated by others who distribute without creating.

More recently, new technologies promise to do for a variety of physical goods and even services what the Internet has already done for information. 3D printers can manufacture physical goods based on any digital design. While home 3D printers are so far quite limited in

1 C 2014 Mark A. Lemley.

2 William H. Neukom Professor, Stanford Law School; partner, Durie Tangri LLP. Thanks to Yochai Benkler, Ryan Calo, Julie Cohen, Deven Desai, David Engstrom, Paul Goldstein, Rose Hagan, Dan Ho, Mike Linksvayer, Mark McKenna, Lisa Larrimore Ouellette, Josh Walker, and participants in workshops at Yale Law School, Stanford Law School, Notre Dame Law School, and Hastings Law School for comments on an earlier draft. 
size and materials, there are tens of thousands of designs available on the Internet already, and larger commercial-scale printers can print anything from circuit boards to rocket engines to human organs on site for the cost of the raw materials and some electricity. Synthetic biology has automated the manufacture not just of copies of existing genetic sequences but any custom-made gene sequence, allowing anyone who wants to create a gene sequence of their own to upload the sequence to a company that will "print" it using the basic building blocks of genetics. And advances in robotics generalize the principle beyond goods, offering the prospect that many of the services humans now provide can be provided free of charge by generalpurpose machines that can be programmed to perform a variety of complex functions. While none of these technologies are nearly as far along as the Internet, they share two essential characteristics with the Internet: they radically reduce the cost of production and distribution of things, and they separate the informational content of those things (the design) from their manufacture. Combine these four developments - the Internet, 3D printing, robotics, and synthetic biology - and it is entirely plausible to envision a not-too-distant world in which most things that people want can be downloaded and created on site for very little money essentially the cost of raw materials. Jeremy Rifkin calls this the zero marginal cost society. ${ }^{3}$

The role of IP in such a world is both controverted and critically important. IP rights are designed to artificially replicate scarcity where it would not otherwise exist. In its simplest form, IP law takes public goods that would otherwise be available to all and artificially restricts their distribution. It makes ideas scarce because then we can bring them into the economy and charge for them, and economics knows how to deal with scarce things. So on one view - the

\footnotetext{
3 Jeremy Rifkin, The Zero Marginal Cost Society (2014).
} 
classical view of IP law - a world in which all the value resides in information is a world in which we need IP everywhere, controlling rights over everything, or no one will get paid to create. That has been the response of IP law to the Internet so far.

But that response is problematic for a couple of reasons. First, it doesn't seem to be working. By disaggregating creation, production, and distribution, the Internet democratized access to content. Copyright owners have been unable to stop a flood of piracy with 50,000 lawsuits, a host of new and increasingly draconian laws, and a well-funded public education campaign that starts in elementary school. They might have more success targeting the intermediaries rather than the individuals consuming content, but because those intermediaries distribute content without regard to what it is, IP law can block piracy there only at the cost of killing off what is good about the Internet. Patent and design patent owners may soon face the same conundrum: unless they strictly control and limit the sale and manufacture of 3D printers and gene printers, they may find themselves unable to prevent the production of unauthorized designs. [And even targeting the intermediaries may prove futile; among the things you can print with a 3D printer is another 3D printer]. The world of democratized, disaggregated production may simply not be one well-suited to the creation of artificial scarcity through law.

Second, even if we could use IP to rein in all this low-cost production and distribution of stuff, we may not want to. The rationale for IP has always been, not to raise prices and reduce consumption for its own sake, but to encourage people to create things when they otherwise wouldn't. More and more evidence casts doubt on the link between IP and creation, however. Empirical evidence suggests that offering money may actually stifle rather than drive creativity 
among individuals. Economic evidence suggests that quite often it is competition, not the lure of monopoly, that drives corporate innovation. And many of the most innovative companies decry patents as interfering with rather than encouraging progress. The Internet may have spawned unprecedented piracy, but it has also given rise to the creation of more works of all types than ever before in history, often by multiple orders of magnitude. Perhaps the Internet has sufficiently reduced the cost of creation that more people will create even without an obvious way to get paid. Or perhaps they never needed the motivation of money, just the ability to create and distribute content. Either way, if the goal of IP is to encourage the creation of new works, the example of the Internet suggests that for some important kinds of creation radically reducing the cost of production decreases, not increases, the need for IP law.

Some scholars have responded to doubts about the traditional justification for IP by offering alternative justifications for IP. But the most common alternatives fare no better than the incentive story in this new world. Commercialization theory, which postulates that we need IP not to encourage creation but to encourage production and distribution of works, is particularly vulnerable to disruption by cost-reducing technologies like the Internet, 3D printers, and gene printers. It may once have been true that even if a book was cheap to write, printing and distributing it took a substantial investment that had to be recouped. But the development of technologies that disaggregate creation from production and distribution, and reduce the cost of the latter to near zero, mean that commercialization-based theories cannot justify IP in the face of new technologies. And the theory that we need IP rights to prompt disclosure of things that would otherwise be kept secret also seems rather quaint. Perhaps it 
made sense in a world where transmission of information was difficult, but in a world in which information flows freely it keeping secrets that becomes the exception rather than the rule.

Far from necessitating more IP protection, then, the development of cost-reducing technologies may actually weaken the case for IP. If people are intrinsically motivated to create, as they seem to be, the easier it is to create and distribute content, the more content is likely to be available even in the absence of IP. And if the point of IP is to encourage either the creation or the distribution of that content, cost-reducing technologies may actually mean we have less, not more, need for IP. ${ }^{4}$

None of this is to say that IP will, or should, disappear entirely or overnight. The cost of producing and distributing content has fallen (and will continue to fall) at uneven rates. Some content, like blockbuster action movies or video games, may be expensive to make for years to come. Other content, like pharmaceuticals, may remain expensive because regulatory barriers raise the cost even as design and manufacturing become cheap. 3D printing, too, may work cheaply and easily for some kinds of goods but less well for others, at least at first. And the case for IP is at its strongest in the case of things that are very expensive to make but cheap to

4 To be sure, there are some who make nonconsequentialist moral claims for IP ownership. See, e.g., Robert P. Merges, Justifying Intellectual Property (2012); Adam Mossoff, Who Cares What Thomas Jefferson Thought About Patents: Reevaluating the Patent "Privilege" in Historical Context, 92 Cornell L. Rev. 953 (2007). There is also a literature that makes moral claims for some limits on IP scholarship. See, e.g., Anupam Chander \& Madhavi Sunder, Copyright's Cultural Turn, 91 Tex. L. Rev. 1397 (2013); Madhavi Sunder, IP3, 59 Stan. L. Rev. 257, 313-15 (2006). Cf. Amy Kapczynski, The Cost of Price: Why and How to Get Beyond Intellectual Property Internalism, 59 UCLA L. Rev. 970 (2012) (attempting to move beyond price, though not necessarily beyond utilitarianism, in evaluating IP). Because those theories treat having an IP right as an end in itself, and one whose value cannot be measured on a utilitarian scale, their advocates may not be swayed by evidence that IP will in the future do more harm than good. While I find those theories thoroughly unpersuasive, it is not my intention to address them here. 
copy. But increasingly those justified instances of IP will become islands in a sea of cheap goods, content, and even services delivered to your home in the form of digital information.

I have argued elsewhere that IP rights are a form of government regulation of market entry and market prices. ${ }^{5}$ We regulated all sorts of industries in the $20^{\text {th }}$ century, from airlines to trucking to telephones to electric power, often because we couldn't conceive of how the industry could survive without the government preventing entry by competitors. Towards the end of that century, however, we experimented with deregulation, and it turned out that the market could provide many of those services better in the absence of government regulation. The same thing may turn out to be true of IP regulation in the $21^{\text {st }}$ century. We didn't get rid of all regulation by any means, and we won't get rid of all IP. But we came to understand that the free market, not government control over entry, is the right default position in the absence of a persuasive justification for limiting that market. The elimination of scarcity will put substantial pressure on the law to do the same with IP.

A world without scarcity requires a major rethinking of economics, much as the decline of the agrarian economy did in the $19^{\text {th }}$ century. How will our economy function in a world in which most of the things we produce are cheap or free? We have lived with scarcity for so long that it is hard even to begin to think about the transition to a post-scarcity economy. IP has allowed us to cling to scarcity as an organizing principle in a world that no longer demands it. But it will no more prevent the transition than agricultural price supports kept us all farmers.

5 See Mark A. Lemley, The Regulatory Turn in IP, 36 Harv. J. L. \& Pub. Pol'y 109 (2013); Mark A. Lemley, Taking the Regulatory Nature of IP Seriously, _ Tex. L. Rev. See Also__ (forthcoming 2014), available at http://papers.ssrn.com/sol3/papers.cfm?abstract_id=2388850. 
We need a post-scarcity economics, one that accepts rather than resists the new opportunities technology will offer us. Developing that economics is the great task of the $21^{\text {st }}$ century. ${ }^{6}$

In Part I, I discuss the traditional economics of scarcity and outline the new technologies that are poised to create an economics of abundance. In Part II, I explore how IP will and should react to those new technologies, using evidence from the Internet as an example. Finally, in Part III I offer some speculations both as to what an economics of abundance would look like and what role IP might play in such a world.

\section{Beyond Scarcity}

\section{A. The Traditional Economics of Goods and Information}

Our economy is based on scarcity. We pay for things because it takes resources - land, raw materials, human labor - to produce them. In general, the more resources it takes to produce them, the more we pay. ${ }^{7}$ The most fundamental graph in economics shows a supply curve and a demand curve. The supply curve slopes up because resources are scarce, and the demand curve slopes down because money too is scarce. Generally speaking, markets meet in the middle - when it costs more to make something than people are willing to pay for it, manufacturers stop making it. When there are exceptions - when customers are willing to pay a great deal for something that is cheap to make - the producer may make a substantial profit

\footnotetext{
6 To be sure, economics has a variety of tools for analyzing markets that differ from the norm. We have economic theories to deal with public goods and natural monopolies in which the marginal cost of producing and distributing goods is zero or very small in relation to the fixed cost of creating those goods. But to date those theories have taken the form either of trying to raise the marginal cost through mechanisms like IP or having the government provide the good on the assumption that private parties won't. Harold Hotelling, The General Welfare in Relation to Problems of Taxation and of Railway and Utility Rates, 6 Econometrica 242 (1938); Summers \& DeLong, supra note _, at 16.

7 See generally Paul Samuelson, Economics.
} 
in the short term. But in the long run, other producers, attracted by the high profit margin, enter and offer the cheap product at a lower price, competing away the extra profit margin. Price settles at marginal cost. $^{8}$

The economics of information are somewhat different. Information is a public good whose consumption is non-rivalrous. Unlike, say, ice cream, my consuming information doesn't prevent you from also consuming it. ${ }^{9}$ Accordingly, the marginal cost of producing information approaches zero (though the physical goods in which information has traditionally been encapsulated, such as books, do cost money to produce and distribute).

Economists worry that things - goods or information - that cost a lot to develop but little or nothing to copy will be underproduced because producers won't be able to charge enough to recoup their investment. ${ }^{10}$ For most public goods, the traditional solution was to regulate market entry, designating one company the exclusive provider of, say, electric power or telephone or cable service for a particular region, and allowing that company to make up its fixed costs by charging its captive customers a price above marginal cost. The IP laws take a similar approach, creating a right to exclude competition in a particular piece of information so that the creator can make up its fixed costs by charging customers a price above marginal cost. Unlike more traditional regulated industries, however, the government does not regulate the

8 See, e.g., Lawrence Summers \& J. Bradford DeLong, The 'New Economy': Background, Historical Perspective, Questions and Speculations, in Economic Policy for the Information Economy 16 (2001) ("the most basic condition for economic efficiency [is] that price equal marginal cost.").

9 See, e.g., Robert P. Merges et al., Intellectual Property in the New Technological Age $12-13$ ( $6^{\text {th }}$ ed. 2012);Tim Wu, The Law and Economics of Information (working paper 2013).

10 F.M. Scherer, Industrial Market Structure and Economic Performance 444 ( 2 d ed. 1980) ("If pure and perfect competition in the strictest sense prevailed continuously ... incentives for invention and innovation would be fatally defective without a patent system or some equivalent substitute."); William M. Landes \& Richard A. Posner, The Economic Structure of Intellectual Property Law (2003). 
price IP owners can charge, instead relying on some combination of the temporary duration of the IP right and imperfect competition from other inventions to keep prices in line. ${ }^{11}$

In effect, the point of IP laws is to take a public good that is in nature nonrivalrous and make it artificially scarce, allowing the owner to control how many copies of the good can be made and at what price. In so doing, IP tries to fit information into the traditional economic theory of goods. The fit is imperfect, though, both because IP's restriction on competition creates a deadweight loss to consumers who would have bought the good at a lower price and because the very existence of the IP right means that competition cannot discipline pricing in the same way it does for goods.

A series of technological changes promise to remake this basic economics in the coming decades. They will do so, not by repealing the basic laws of economics, but by fundamentally changing both the cost and the nature of the supply side of the equation.

\section{B. The Internet and Information Economics}

I begin with the most familiar example: the Internet. It has become trite to observe that the Internet has remade the economics of information. Many lament the risk to old business models, ${ }^{12}$ while others praise the benefits of instant access to all the world's information. ${ }^{13}$ ।

11 On imperfect competition in IP, see, for example, Michael Abramowicz, An Industrial Organization Approach to Copyright Law, 46 Wm. \& Mary L. Rev. 33 (2004); Christopher S. Yoo, Copyright and Product Differentiation, 79 N.Y.U. L. Rev. 212, 218-19 (2004); Christopher S. Yoo, Copyright and Public Good Economics: A Misunderstood Relation, 155 U. Pa. L. Rev. 635, 706-14 (2006). For an argument that more IP rights confer significant power over price than previously suspected, see Mark A. Lemley \& Mark P. McKenna, Is Pepsi Really a Substitute for Coke? Market Definition in Antitrust and IP, 100 Geo. L.J. 2055, 2081-91 (2012).

12 See, e.g., Jaron Lanier, Who Owns the Future 51 (2013) (“Copying a musician's music ruins economic dignity.").

13 See, e.g., John Tehranian, Infringement Nation (2012). 
will discuss the effects of these changes below. For now, though, it is worth focusing attention on what exactly the Internet changed about content distribution.

\section{Content Creation and Distribution Before the Internet}

Before the Internet, the creation and distribution of content was a large-scale business operation. While anyone could write a song or a movie script, actually producing a record or a movie required commercial facilities. Further, even for industries where the creation of content was fairly cheap (say, writing a book, which didn't require much more than a typewriter), distributing that work to a wide audience required a commercial network. Writing a book may have been cheap, but printing that book required a substantial factory, and distributing it to the masses required a fleet of trucks and a network of brick-and-mortar stores. And the companies that owned those factories, trucks, and stores invested the most in producing and distributing a work and accordingly took the lion's share of the revenue from the sale of that work (often $80 \%$ or more, as with major label record and book publishing contracts). ${ }^{14}$

Notably, it was not just the distribution of legitimate copyrighted content that required a substantial investment; counterfeiting did too. ${ }^{15}$ Anyone who wanted to sell fake records or counterfeit books in the 1970s had to invest in a facility to manufacture the physical goods, a network to distribute those copies to "retailers," and a group of people to sell the goods - all

14 See, e.g., Courtney Love, Courtney Love Does the Math, Salon, June 14, 2000, http://www.salon.com/2000/06/14/love 7/ (explaining how the economics of record label contracts are stacked against artists, and noting that getting even $20 \%$ of revenues before recoupment is unlikely). As Love puts it, "[t]he system's set up so almost nobody gets paid."

15 See Mark A. Lemley \& R. Anthony Reese, Reducing Digital Copyright Infringement Without Restricting Innovation, 56 Stan. L. Rev. 1345 (2004) (documenting this shift in costs). 
while avoiding the watchful eyes of the police. True, the retailers may have had lower overhead - operating from a card table on a street corner rather than a permanent store. But as counterfeiters grew in scale, they faced increased costs and a greater chance of detection.

Copying other types of works, like movies, was virtually impossible until the development of the VCR in the late 1970s. In the 1980s, the development of audio cassette tapes allowed individual consumers to copy music from each other or over the airwaves. Both technologies prompted dire warnings that counterfeiting would cause the collapse of the content industries. ${ }^{16}$ In fact, however, both technologies suffered from many of the same limitations as previous ones. They may have allowed end users to engage in small-scale personal copying more easily, but they did nothing to change the fundamental economics of counterfeiting as a business.

\section{The Internet Changes Things}

The Internet (and digital media more generally) brought two related changes that fundamentally altered this dynamic. First, the rise of digital media permitted the separation of the act of creation from the acts of production and distribution. A new creative work could now be instantiated entirely as information, rather than the creation of a physical product that itself had to be reproduced. Creative works had (mostly) always existed as conceptual things separate from their physical form; the 1976 Copyright Act makes it clear that the copyrighted "work" is separate from a "copy" that embodies that work, even if (as with an oil painting) the

16 For discussion of this history, see Mark A. Lemley, Is the Sky Falling on the Content Industries?, $9 \mathrm{~J}$. Telecomm. \& High Tech L. 125 (2011). 
only embodiment of the work is in that physical copy. ${ }^{17}$ Buying a physical copy of something even the only physical copy - doesn't give you rights in the copyrighted work embodied in that copy. But with the rise of digital technology, the work could be created entirely as information. This happened first with text - books were written in computers rather than on paper. But today music, movies, and art can be made entirely of information. ${ }^{18}$

This led to a second, related change: the democratization of content distribution. Once a work could be instantiated entirely in information, the copying of that work no longer required a factory to produce it or a fleet of trucks and stores to distribute it. The work could be transmitted to others with no loss of quality and at virtually no cost. The fact that distribution was so cheap, in turn, meant that anyone could do it. Artists did not have to distribute their own work (or have book publishers or record companies do it for them). Anyone can (and does) distribute content in digital form.

The combined effect of these changes was to fundamentally alter the economics of the creative industries. ${ }^{19}$ Existing content is no longer scarce. Once created, it costs virtually nothing to reproduce, and anyone can copy and distribute it. On the one hand, this is an enormous boon for artists. You no longer need turn over $80 \%$ of your revenues to a major-label record company in exchange for the company mass-producing hundreds of thousands of plastic

\footnotetext{
17 U.S.C. $§ 101$ (defining both "fixed" and "literary work" by distinguishing the intellectual creation from its tangible physical embodiment). For a discussion of the history of copyright as moving further and further away from protecting physical embodiments toward protecting more abstract information concepts, see David Nimmer, Copyright and the Fall Line, 31 Cardozo Arts \& Ent. L.J. 803, 811-13 (2013). 18 Notably, some kinds of creative works, like choreography or sculpture, are harder to instantiate in digital form. What is captured in information is usually a representation of the thing that differs in certain respects from the thing itself. But works of that sort have always been the hardest to copy. 19 John M. Newman, Copyright Freeconomics, 66 Vand. L. Rev. 1409 (2013).
} 
discs and shipping them to retail stores around the country. Want your music available to a global audience? Click a few buttons and it's done.

On the other hand, the democratization of content distribution has also fundamentally changed the nature of IP infringement. Counterfeiters too no longer need to build factories or hire trucks and teams of retailers. Indeed, counterfeiting as a business seems in just as much jeopardy as the major record labels from the rise of the amateur copyist. The democratization of copying and distribution has made it far easier than ever before in history to communicate content to others. But by eliminating scarcity, it may have made it harder than ever before to get paid for doing so. ${ }^{20}$

\section{The Coming Information Economics of Things}

While the changes the Internet has wrought in digital content are well-known, what is less well known is that a similar set of changes is poised to sweep through the economy of goods and even services. In this section, I discuss three new technologies that promise the same sort of changes for goods and services that the Internet has brought for content. ${ }^{21}$ Each of these technologies is at an early stage; there are many obstacles on the path to success. But each has the potential to revolutionize a sector of our economy - not next year, but certainly in our lifetimes.

\footnotetext{
20 Harry Surden argues that the true scope of IP law is a function not only of the law on the books but also of the technological cost of creation and copying. Thus, as the cost of reproduction changes, "existing activities can become dramatically more expansive in capacity, can acquire entirely new properties, and previously infeasible activities can become feasible." Harry Surden, Technological Cost as Law in Intellectual Property, 27 Harv. J. L. \& Tech. 1 (2013).

21 Rifkin offers other examples, notably crowd-sourced production of renewable energy, the sharing economy, and the Internet of Things. Rifkin, supra note _, at 69-88.
} 


\section{3D Printing}

Perhaps the best known of these new technologies is 3D printing. As the name

suggests, 3D printing is a developing technology that converts information into a physical item, just as regular computer printing does - with the twist that the physical item exists in three dimensions rather than only two. A typical 3D printer will use as input a form of extruded plastic. The user loads a blueprint into the computer attached to the 3D printer, and the printer deposits the plastic, layer by layer, until it has made a 3D object. ${ }^{22}$

3D printing is in its infancy as a technology, but already the potential for transformation is clear. Cheap, home 3D printers can already print spare parts, small sculptures, and a variety of household goods. 3D printers can print operable mechanical objects, including clocks and (infamously) a plastic gun. ${ }^{23}$ Larger, more expensive 3D printers - mostly in use now at manufacturing facilities or at foundries like Shapeways ${ }^{24}$ but also available for consumer use at Staples ${ }^{25}$ - can print from a variety of different raw materials, including metal powders, fabrics, ${ }^{26}$ and paper that can generate wood products, ${ }^{27}$ and can therefore make much more

22 For a discussion of the basics of 3D printing, see, for example, Charles W. Finnochiaro, Personal Factory or Catalyst for Piracy? The Hype, Hysteria, and Hard Realities of Consumer 3-D Printing, 31 Cardozo Arts \& Ent. L.J. 473 (2013); Daniel Harris Brean, Asserting Patents to Combat Infringement via 3D Printing: It's No "Use,", 23 Fordham Intell. Prop., Med. \& Ent. L.J. 771 (2013).

${ }^{23}$ See, e.g., http://web.media.mit.ed/ peter/about/Portfolio-Peter-Schmitt.pdf (clocks); Nora Freeman Engstrom, 3D Printing and Product Liability: Identifying the Obstacles, $162 \mathrm{U}$. Pa. L. Rev. Online 35 (2013) (guns). For a catalog of other remarkable 3D printing successes, see Susson, supra note _, at 1218.

24 http://www.shapeways.com.

25 Sean Buckley, Staples is Launching an In-Store 3D Printing Service (April 10, 2014), http://www.engadget.com/2014/04/10/staples-is-launching-an-in-store-3d-printing-service/.

26 http://3dprintingindustry.com/fashion.

Rifkin, supra note _, at 95. 
complicated devices. ${ }^{28}$ People print anything from clothes to kayaks. ${ }^{29}$ 3D printers are even printing functional electronic equipment. ${ }^{30}$ Some manufacturing facilities have switched to making complex devices such as jet turbines and rocket engines on 3D printers because the printers replicate things exactly every time and therefore reduce error tolerance. ${ }^{31}$ The ground-up assembly process makes it possible to print shapes that cannot be cut or shaped from a block of existing material. ${ }^{32}$ Companies today even 3D print artificial human limbs and organs. $^{33}$

While the current state of 3D printing makes it useful only for certain types of products, there is reason to think that 3D printing will get both cheaper and better in the not-too-distant future. $^{34} 3 \mathrm{D}$ printers look right now like the computer industry did in 1976 - a set of large, expensive machines used by businesses and a fringe of cheap, homemade computers used

28 See Brean, supra note __, at 780.

29 Paul Ridden, World's First 3d-Printed Kayak Takes to the Water, Gizmag, Mar. 24, 2014, http://www.gizmag.com/3d-printed-kayak/31343/.

30 See, e.g., Lucas Mearian, This 3d Printer Technology Can Print a Game Controller, Electronics and All, Computer World, April 25, 2014, http://www.computerworld.com/s/article/9247934/This_3D_printer_technology_can_print_a_game_c ontroller_electronics_and_all.

31 See, e.g., Jason Paur, NASA Fires Up Rocket Engine Made of 3D Printed Parts, Wired, Aug. 28, 2013, available at http://www.wired.com/autopia/2013/08/nasa-3d-printed-rocket-engine/; Leslie Langnau, 3D Printer Helps Window Treatment Maker Reduce Design Cycle, http://www.makepartsfast.com/2011/11/2756/3d-printer-helps-window-treatment-maker-reducedesign-cycle/ (noting that 3D printers reduce manufacturing errors and rework).

32 See Michael Weinberg, It Will Be Awesome If They Don't Screw It Up: 3D Printing, Intellectual Property, and the Fight Over the Next Great Disruptive Technology, http://www.publicknowledge.org/files/docs/3DPrintingPaperPublicKnowledge.pdf.

${ }_{33}$ See, e.g., Harrison Jacobs, A UK Surgeon Successfully 3D Printed and Implanted a Pelvis, Bus. Insider, Feb. 17, 2014, available at http://www.businessinsider.com/uk-surgeon-implanted-a-3d-printed-pelvis2014-2; http://www.robohand.net (a company that has printed and attached more than 200 3D-printed artificial hands); Martin LaMonica, 3D Printer Produces New Jaw for Woman, CNET (Feb. 6, 2012), http://news.cnet.com/8301-11386 3-57372095-76/3d-printer-produces-new-jaw-for-woman.

34 Even a relative skeptic like Vivek Wadhwa acknowledges that "[w]e will surely see Star Trek-like replicators and large-scale 3D manufacturing plants one day. But this won't be until sometime in the next decade." Vivek Wadhwa, Let's Curb Our 3D-Printer Enthusiasm, Folks, Wash. Post, Aug. 2, 2013. 
primarily by hobbyists. ${ }^{35}$ But computers rapidly joined the mainstream in the 1980 s as

processing power increased and size and cost decreased, making a personal computer a plausible investment. ${ }^{36}$ We should expect similar trends in 3D printing. The raw materials for most applications are relatively cheap. Printer designs and products that can be designed on them are increasingly available. ${ }^{37}$ The range of things that can be 3D printed will grow rapidly; one company began 3D printing of human organs in $2013,{ }^{38}$ and there is even a prototype of a 3D printer that can print a house. ${ }^{39}$ Researchers are working on 3D printers that can print food. ${ }^{40}$ The development of commercial printers and their increase in use should reduce the cost of manufacturing more sophisticated printers, and as demand grows economies of scale should bring the cost down even further. Most notably, 3D printers can even print the parts for

35 Cf. Babbage Difference Engine: The PC All Over Again?, Economist, Sept. 9, 2012, http://www.economist.com/blogs/babbage/2012/09/3d-printing ("In many ways, today's 3D printing community resembles the personal computing community of the early 1990s."). I actually think a better analogy is the Homebrew Computer Club of DIY computer enthusiasts in the 1970s. http://en.wikipedia.org/wiki/Homebrew Computer Club.

${ }^{36}$ http://en.wikipedia.org/wiki/History of personal computers (describing "an explosion of low-cost machines known as home computers that sold millions of units before the market imploded in a price war in the early 1980s").

37 3D printers are available now for less than $\$ 1000$ - comparable to what a laser printer cost in 1985. Cyrus Farivar, California' First 3D Printer Retail Store to Sell \$600 Model, Ars Technica, Sept. 21, 2012, http://www.arstechnica.com/business/2012/09/californias-first-3d-printer-retail-store-to-sell-600model. There are dozens of repositories for 3D printer designs. Just one of those repositories, CADYou, has over 20,000 designs. 37 Marketplaces to Share, Buy, and Sell Designs for 3D Printing, Making Society, July 11, 2013, available at http://makingsociety.com/2013/07/37-3d-printing-marketplaces-toshare-buy-and-sell-3d-designs/.

38 Lucas Mearlan, The First 3D Printed Organ - a Liver - Is Expected in 2014, ComputerWorld, Dec. 26, 2013.

39 The 3D Printer That Can Build a House in 24 Hours, Nov. 20, 2013, available at http://innovation.uk.msn.com/design/the-3d-printer-that-can-build-a-house-in-24-hours; Laura Secorun Palet, Who Built My Home? A 3D Printer, http://www.ozy.com/fast-forward/3-d-printedhouses/31179.article (May 7, 2014).

40 Adam Clark Estes, 3D Printing Now Lets Us Manufacture Blood Vessels, Organs, Food, The Atlantic Wire, Sept. 16, 2011, available at http://www.theatlanticwire.com/technology/2011/09/3d-printingblood-vessels/42608/. 
assembling new 3D printers, ${ }^{41}$ which suggests that 3D printers can effectively improve themselves over time. $^{42}$

A world in which sophisticated 3D printers are widely available would change the economics of things in a fundamental way. ${ }^{43} 3 \mathrm{D}$ printers, like the Internet, separate things into their information content and their manufacturing. ${ }^{44}$ By doing so, they eliminate the cost of distribution (since the thing of interest can be printed on site) and substantially reduce the cost of manufacturing (since the only costs will be the raw materials and electricity). Like the Internet, the democratization of production of things can be both good and bad. A world in which everyone has advanced 3D printers at home or available in a public facility is a world in which manufactured goods no longer have to be produced in bulk and are no longer scarce. ${ }^{45}$ But it is also a world in which the manufacture and sale of newly-designed things becomes harder and harder to control. All someone need do is download a design from the Internet and they can print that design without paying. The result is what Deven Desai and Gerard Magliocca have called the "Napsterization" of things. ${ }^{46}$ But while Napster and the Internet

41 See https://www.thingiverse.com/explore/newest/3d-printing/3d-printer-parts/ (cataloging designs for 3D printer parts to be printed on a 3D printer).

${ }^{42}$ [cite self-assembling 3D robots]

43 For a skeptical view that 3D printers are unlikely to pose the same challenges as the Internet, see Charles W. Finnochiaro, Personal Factory or Catalyst for Piracy? The Hype, Hysteria, and Hard Realities of Consumer 3-D Printing, 31 Cardozo Arts \& Ent. L.J. 473 (2013).

44 Indeed, Jeremy Rifkin refers to the production of goods in a 3D printer economy as "infofacturing." Rifkin, supra note _, at 89.

45 See Neil Gershenfeld, How to Make Almost Anything: The Digital Fabrication Revolution, 91 Foreign Aff. 43 (2012).

46 Deven R. Desai \& Gerard N. Magliocca, Patents, Meet Napster: 3D Printing and the Digitization of Things, 101 Geo. L.J. _ (forthcoming 2014), available at http://papers.ssrn.com/sol3/papers.cfm?abstract id=2338067; James Grimmelman, Indistinguishable from Magic: A Wizard's Guide to Copyright and 3D Printing, 71 Wash. \& Lee L. Rev. __ [draft at 13-14] (forthcoming 2014) ("Music and movies have had enforcement problems in spades since Napster and its nephews. Now that the world of bits is colonizing the world of atoms, the makers of things are about to 
implicated copyright law, 3D printing is likely to affect the owners of utility patents and design patents, which cover the making of physical things.

\section{Synthetic Biology and Bioprinting}

If the automated manufacturing of things in your own home with 3D printers sounds a bit like science fiction, how about the automated manufacturing of new genes? The emerging discipline of synthetic biology promises to take what has been a craft - combining gene fragments from two different species to create genetically modified organisms - and make it into a true engineering discipline.

Traditional biotechnology is a hit-or-miss discipline. Scientists try to figure out what existing genes do, and then take snippets of genes from one organism and splice them into another in hopes of generating a modified organism with some of the characteristics of both sources. ${ }^{47}$ This has led to some dramatic successes, from the cheap production of human growth hormone in bacteria to the development of disease-resistant crops. ${ }^{48}$ But it is at its base guesswork. And it has produced many more failures, particularly in the area of human gene therapy. $^{49}$

learn that they are less special than they may have thought. They confront exactly the same enforcement challenges.").

47 See Drew Endy, Foundations for Engineering Biology, 438 Nature 449, 449 (2005). For a discussion of the IP issues synthetic biology presents, see Sapna Kumar \& Arti Rai, Synthetic Biology: the Intellectual Property Puzzle, 85 Tex. L. Rev. 745 (2007).

48 See, e.g., Bowman v. Monsanto, 133 S.Ct. 1761 (2013) (adjudicating dispute over patent on genetically modified soybean seeds).

49 See, e.g., Adam J. Kolber, Will There Be a Neurolaw Revolution?, 89 Ind. L.J. 807, 828 (2014) ("gene therapies have been slower to develop than many expected"); Stephen J. Morse, Avoiding Irrational NeuroLaw Exuberance: A Plea for Neuromodesty, 62 Mercer L. Rev. 837, 856 (2011) ("The genome was fully sequenced in 2001, and there has not been one resulting major advance in therapeutic medicine since."). 
Synthetic biology offers something much more radical: the opportunity not just to take genetic pieces already created in nature and move them around, but the ability to build something entirely new. At its most extreme, synthetic biology involves engineering a genome from the ground up to create new characteristics. ${ }^{50}$ But even modifications to existing organisms represent something different than traditional biotechnology has given us so far. Scientists have already engineered E. coli bacteria to change their smell - not just by replacing the gene that causes the odor, but by creating an if-then statement in the genetic code, causing the bacteria to give off a different smell depending on whether it was reproducing. ${ }^{51}$ Potential applications include medical diagnostic tests that can alert people to diseases or health risks by changing the color or smell of their urine or feces. ${ }^{52}$ Scientists have also programmed genes to do things unrelated to their own functions, such as storing bits of information or acting as a logic gate to perform a simple mathematical calculation..$^{53}$ More radically, they have made entirely new forms of bacteria different than anything found in nature. ${ }^{54}$ Genes might become not only computers, but builders. Imagine a plant genetically modified to grow into the shape of a building. Voila: cheap, organic, self-constructing housing. ${ }^{55}$

50 See, e.g., Andrew Pollack, Researchers Report Breakthrough in Creating Artificial Genetic Code, N.Y. Times, May 7, 2014 (describing the addition of two new nucleotides, $X$ and $Y$, to the normal $A, C, G$, and T.).

51 See, e.g., http://seekerblog.com/2007/01/08/mits-drew-endy-on-synthetic-biology/.

52 Tanya Lewis, Incredible Tech: How to Engineer Life in the Lab, Live Science, Nov. 18, 2013, available at http://www.livescience.com/41287-incredible-technology-how-to-engineer-life.html.

53 See, e.g., Nicholas Koutsoubelis, Quantitative in Silico and in Vitro Characterization of the Recombinase Addressible Data Storage, July 16, 2012, available at http://openwetware.org/images/c/cb/Koutsoubelis_BS_Thesis_Stanford_Freiburg.pdf

54 See Synthetic Genomics Applauds the Venter Institute's Work in Creating the First Synthetic Bacterial Cell, http://www.syntheticgenomics.com/media/press/051910.html.

55 See, e.g., Tom McKeag, Will Synthetic Biology Lead to Truly Living Buildings?, GreenBiz, June 16, 2010, available at http://www.greenbiz.com/blog/2010/06/16/will-synthetic-biology-lead-truly-livingbuildings. 
These new technologies depend on a completely different form of biotechnology manufacturing. Rather than taking genes from existing organisms, a scientist who wants to create a NAND logic gate in genetic material must start from scratch. Accordingly, at the base of all new synthetic biology is a gene assembler. ${ }^{56}$ This is a machine that serves as a sort of 3D printer for genes, drawing from streams of the four base pairs that make up all genetic material (As, Cs, Gs, and Ts) and linking them together into a new, synthetic strand of genetic material. Write the (genetic) code you want, and the machine assembles it, base pair by base pair. Gene assemblers already exist, and their cost is falling substantially. And with a gene assembler and bottles of each of the four base pairs, you can "print" any gene you want, whether an existing one or one you have just made up.

Gene assemblers promise to do just what 3D printers will and the Internet already does: separate design from manufacturing, eliminate the need for distribution, and put manufacturing in the hands of the masses. The design of an organism, like the design of a rocket engine or the notes of a song, is just information. ${ }^{57}$ That information is already being stored in open-source databases from which anyone can download it. ${ }^{58}$ Plug that information and a stream of simple raw materials into a gene assembler, and you can make the basic components of any living thing you can imagine. ${ }^{59}$ And as the Internet has shown, information in its pure form is cheap and easy to copy and notoriously hard to control. As genetic

56 See, e.g., Monya Baker, De Novo Gene Assembly: What Every Biologist Should Know, 9 Nature Methods 333 (2012).

57 Association for Molecular Pathology v. Myriad, 133 S.Ct. 2107 (2013).

58 The BioBricks Foundation, for instance, collects available gene sequences, cataloged by function. http://parts.igem.org/Main Page.

59 To be sure, the gene you print isn't ready to use; it still needs to be put into a living organism. But that too is increasingly easy to do. 
information becomes just that - information, and as manufacturing becomes cheap and distributed, the economics of biotechnology will begin to look more and more like the economics of content distribution. One application of this is copying existing genes. ${ }^{60}$ But the more interesting applications involve creating entirely new organisms.

Developing an organism from scratch is likely to be hard. But there is a second way in which the separation of information from production will drive advances in synthetic biology. Scientists can develop individual, modular building blocks that others can assemble into organisms that serve a desired function. If I want a gene component that stores data, I shouldn't have to recreate one from scratch; someone has probably already coded such a component. ${ }^{61}$ Synthetic biologists are developing collections of "biobricks" - individual modules that can be put together in organisms. Because these bricks are information, they can be shared and recombined in numerous ways.

Combining this technology with 3D printing has a synergistic effect. We have already seen that 3D printers can generate artificial human limbs and body parts. But add in the ability to generate biological material and you get the possibility of bioprinting - the automated generation of living cells with whatever genetic material you desire. Bioprinters are already generating human cartilage tissue, ${ }^{62}$ and doctors in 2014 implanted a 3D printed skull in a

60 See Andrew Pollack, Developing a Fax Machine to Copy Life on Mars, N.Y. Times, Nov. 18, 2013, at B1 (discussing Craig Venter's project to copy transmit DNA information and transpose it into a blank cell; "the genetic code that governs life can be stored in a computer and transmitted just like any other information.")

61 Not yet, it turns out, but they're working on it. See Koutsoubelis, supra note _. Henry Fountain, At the Printer, Living Tissue, N.Y. Times, Aug. 20, 2013, at D1. 
person. ${ }^{63}$ And scientists are working on bioprinting machines - devices based on cellular tissue that can move on their own. ${ }^{64}$ Further, we have seen the development of DIY biolabs, ${ }^{65}$ suggesting that as the cost of these technologies declines they will be widely accessible, if not in the home then in a variety of locations for public use.

Synthetic biology is at an earlier stage than 3D printing; I don't expect to be printing my own organisms any time soon. But it is certainly possible to imagine a time in which every doctor's office can generate custom genes to order. And the ability to manipulate organisms to do anything imaginable may lead to new products that are currently unimaginable. We allow the patenting of newly-created organisms ${ }^{66}$ and of shorter DNA sequences so long as they are not taken from nature. ${ }^{67}$ But those patents are essentially directed to the informational content of the genes, and their owners will face many of the same issues copyright owners face on the Internet.

\section{Robotics}

Both 3D printing and synthetic biology promise to revolutionize the making of various types of things. But the revolution will not end there. Advances in robotics may bring the same sorts of disruption to the service economy, and for similar reasons.

63 http://www.nbcnews.com/science/science-news/medical-first-3-d-printed-skull-successfullyimplanted-woman-n65576.

64 Henry Fountain, Printing Out a Biological Machine, N.Y. Times, Aug. 20, 2013, at D2.

65 See, e.g., Melissa Panduka, Free the Labs! The Biopunk Revolution is Here, Ozymandias, Feb. 27, 2014, available at http://www.ozy.com/fast-forward/the-biopunk-revolution/.

66 Diamond v. Chakrabarty, 447 U.S. 303 (1980).

67 Association for Molecular Pathology v. Myriad, 133 S.Ct. 2107 (2013). 
Robots have already remade substantial sectors of the industrial economy, replacing human workers for certain sorts of repetitive tasks. ${ }^{68}$ And certain very simple robots like the Roomba vacuum cleaner have made it into the mass consumer market. But robots are poised to greatly expand the number and complexity of tasks they can perform, a fact that has significant implications for both industrial and consumer services. Robots may clean our houses, but they may also serve us meals and drive our cars. ${ }^{69}$ These tasks were traditionally thought beyond machine capabilities because they required judgment, but Google's driverless cars have demonstrated that machines can engage in adaptive learning of complex tasks. ${ }^{70}$ Some studies have suggested that nearly half of today's jobs could be automated in the next two decades. ${ }^{71}$ Honda projects that it will sell as many robots in 2020 as it does cars. ${ }^{72}$

The robots mentioned above have one thing in common: they are special-purpose machines designed to achieve a single goal. A car body welding robot welds car bodies; a Roomba cleans the floor. ${ }^{73}$ By contrast, the coming generation of robots will be generalpurpose machines that can be programmed to achieve a variety of goals. And that programming will be updatable; as people design new programs for a robot to run, the robot

68 See, e.g., David J. Hill, 1 Million Robots to Replace 1 Million Human Jobs at Foxconn? The First Robots Have Arrived, SingularityHUB, Nov. 12, 2012, available at http://singularityhub.com/2012/11/12/1million-robots-to-replace-1-million-human-jobs-at-foxconn-first-robots-have-arrived/.

69 See, e.g., Anne Eisenberg, More Roles for Robots as Prices Fall, N.Y. Times, March 3, 2014, at 14.

70 Chunka Mui, Will the Google Car Force a Choice Between Lives and Jobs?, Forbes, Dec. 19, 2013, available at http://www.forbes.com/sites/chunkamui/2013/12/19/will-the-google-car-force-a-choicebetween-lives-and-jobs/.

71 See, e.g., Coming to an Office Near You, The Economist, Jan. 18, 2014, available at http://www.economist.com/node/21594298/print

72 Juha Ainoa et al., The Digital Evolution - from Impossible to Spectacular, in Bit Bang: Rays to the Future 8, 31 (2009), available at http://libltkk.fi/Reports/2009/isbh9789522480781.pdf.

73 Ryan Calo refers to this as "closed robotics." Ryan Calo, The Need to Be Open: U.S. Laws are Killing the Future of Robotics, Mashable, Jan. 1, 2014, available at http://mashable.com/2014/01/01/us-lawrobotics-future/ 
will be able to download that new programming and learn new tasks. ${ }^{74}$ That is a critical difference, for two reasons. First, it means that consumers and small businesses need not buy a different robot for each task. The ability to buy a robot that will perform multiple functions will help robots break into the consumer and retail-service markets. Indeed, we have already seen robots make substantial inroads into logistics, retail, and even white-collar service industries. ${ }^{75}$ Second, the updatability of general-purpose robots means that the technology can advance with the speed of software, not hardware. ${ }^{76}$ New features can be implemented, and bugs fixed, without having to buy and ship a new device. Anyone can develop the software tools to customize their own robots. ${ }^{77}$ When combined with 3D printers, robots may eventually even be able to upgrade their own hardware. ${ }^{78}$

The nature of a general-purpose robot has much in common with the previous three technologies. ${ }^{79}$ As with the Internet or 3D printing, we are in the process of separating the informational content of a design (here, software for performing a service) from the physical

74 Ryan Calo, Open Robotics, 70 Md. L. Rev. _, [draft at 102-03] (2012). While open source vs. proprietary code is related to general-purpose vs. special-purpose machines - open source systems tend to be general purpose - the two issues are distinct. A system can be proprietary yet general-purpose, as the Apple computer architecture is. Calo uses the term "open robotics" to refer to general-purpose robots not dedicated to a particular use, whether they run proprietary or open-source software. Id. at [104] For a discussion of the general-purpose nature of computers, see, e.g., Jonathan Zittrain, The Future of the Internet and How to Stop It 19 (2006).

75 See Rifkin, supra note _, at 125-27 (discussing Amazon's roboticized warehouses, self-driving cars, and the rise of vending machines and self-checkout terminals at stores and airports).

76 See Calo, Need, supra note __ ("Consumer robotics started off closed, which helps to explain why it has moved so slowly."). Calo argues that we need a form of legal immunity for the designer of open robots, just as we do for providers of general-purpose computers or Internet service providers. Id. Like those technologies (and like 3D printers and gene assemblers), the maker of the device in this world is divorced from the uses to which the device might be put.

77 See Chris Anderson, Makers: The New Industrial Revolution 17 (2012).

78 Cite self-assembling robot article

79 For an explicit comparison, see Ryan Calo, Robotics and the New Cyberlaw (working paper 2014) (discussing the legal parallels between the development of Internet law and the coming law of robotics). 
implementation of that design. Once we do that, the automation revolution that has already hit factories and distribution centers ${ }^{80}$ will expand to other sectors of the economy. Services that once required specialized expertise in stores or factories will increasingly be performed by robots in homes or small businesses. The marginal cost of implementing that design drops towards zero, because for many services all that is required is to program an existing robot with data over the Internet. Services, like content, things, and biologics, will cease to be scarce.

Robotics implicates a range of IP rights, including copyright, patent, and design patent. Robots are a combination of hardware and software, and the hardware must still be manufactured, though there are intriguing prospects for using 3D printers to help generate robots. $^{81}$ But the ability to upgrade robots by downloading information will present many of the same challenges the Internet has presented for content.

\section{IP in a Post-Scarcity World}

\section{A. The Internet Experience}

If technology offers a world in which goods and services are no longer scarce, how should IP law respond? Basic IP theory suggests a clear answer: a world in which content is separated from production needs more and stronger IP to restore the scarcity we have lost. The logic goes like this. IP is designed to solve a public goods problem that arises because it is cheaper to be an imitator than an inventor. The greater the disparity between the cost of

80 See Rotman, supra note _ (discussing Amazon.com's use of robots to select, pack, and ship goods from warehouse shelves).

81 See, e.g., Loren Grush, MIT Researchers Develop 3D-Printed Robots That Self-Assemble When Heated, http://www.digitaltrends.com/cool-tech/mit-researchers-developed-3d-robots-self-assembleheated/\#!XwMkR (May 31, 2014).

Self-assembling robots. What could possibly go wrong? 
inventing or creating and the cost of imitating, the more need there is for IP to encourage people to be creators rather than imitators. ${ }^{82}$ In effect, IP law artificially raises the cost of imitation in order to make it at least as costly as creation. The technologies I described in Part I separate the act of creation from the acts of reproduction and distribution, and dramatically reduce the cost of the latter two. Accordingly, they exacerbate the public goods problem of IP theory by making it much cheaper to imitate than to create. According to standard IP theory, lots of people will engage in illegal copying but no one will create under those circumstances. We must artificially increase the cost of production and distribution to rebalance incentives. And because the technology makes reproduction and distribution so cheap and easy, we must increase the cost quite a lot in order to restore the scarcity that is the foundation of our economic order. As Rob Merges puts it, "[i]n an economy where intangible assets are more valuable than ever, IP is more important than ever." 83

We have seen these arguments play out in the Internet, the technology that is furthest advanced of the four I have discussed. Consistent with IP theory, as the cost of reproduction and distribution dropped to zero, piracy became rampant on the Internet. ${ }^{84}$ The companies that produced content in the pre-Internet world worried that they could not make money in an

82 For discussions of this classic economic theory of IP, see, e.g., William M. Landes \& Richard A. Posner, The Economic Structure of Intellectual Property Law 40 (2003); Mark A. Lemley, The Economics of Improvement in Intellectual Property Law, 75 Tex. L. Rev. 989, 993-97 (2007); Wendy J. Gordon, An Inquiry into the Merits of Copyright: The Challenges of Consistency, Consent, and Encouragement Theory, 41 Stan. L. Rev. 1343, 1435 (1989).

83 Robert P. Merges, Justifying Intellectual Property 290 (2012).

${ }^{84}$ The US government estimates the cost of piracy at as much as $\$ 250$ billion per year. United States Department of Justice, Prosecuting Intellectual Property Crimes, http://www.justice.gov/criminal/cybercrime/docs/ipma2006.pdf. But those numbers are almost certainly wildly inflated, because the government assumes that every item copied for free and every \$20 Rolex knockoff would in fact have been purchased at full price. As one report put it, that number "is as fake as an imitation Tommy Hilfiger T shirt." Adam L. Penenberg, Cops, Cash and Counterfeits, Forbes, Dec. 28, 1998, at 70. 
environment where copying was so easy. Many have lamented the Internet as the end of the content industries, ${ }^{85}$ and indeed some (though not all) of those industries saw their revenues decline as consumers switched from buying content in physical form to downloading it, often for free. ${ }^{86}$

The content industries responded just as IP theory said they should. They persuaded Congress to pass a multitude of new laws, criminalizing copyright infringement on the Internet even if done for no financial gain ${ }^{87}$ and ramping up the penalties for copyright infringement to an extreme degree. ${ }^{88}$ They filed tens of thousands of lawsuits against people who posted copyrighted content online. ${ }^{89}$ They sued anyone with even a vague connection to the pirates, from sellers of software to content hosting services to search engines to providers of Internet

85 See Lemley, Sky Falling, supra note __, at __:

Are the content industries doomed? They certainly seem to think so. The music industry tells us, as their revenues decline because of file sharing, "we can't compete with free," and so we're history. No one is going to create new music anymore. The video industries seem to be getting in on the act, too. They've showed up behind closed doors in Washington, D.C. to complain about the prospect of a national broadband plan, because broadband is simply going to make it easier for people to pirate video over the Internet. "We've got to do something about it," they tell us, "or no one is going to make movies anymore."

86 Music industry revenues have declined from nearly $\$ 20$ billion to only $\$ 7$ billion per year. Lunney, supra note _. Newspapers have also seen declining revenues. Mark Cooper, Structured Viral Communications: The Political Economy and Social Organization of Digital Disintermediation, $8 \mathrm{~J}$. TELECOMM. \& HIGH TECH. L. _ (2011). By contrast, both book publishers are making record revenues. See Waldfogel, Storming, supra note __ (books). Movie studios are a more mixed bag; total revenues are down somewhat, but so are costs, and profit margins are up. Cynthia Littleton, Major Film Studios Prosper on the Margins, Variety, April 18, 2013, available at http://variety.com/2013/biz/news/majorfilm-studios-prosper-on-the-margins-1200376494/.

87 See, e.g., NET Act, 17 U.S.C. $\$ 506(\mathrm{a})(1)(\mathrm{B})$.

88 Criminal copyright infringement is a felony that carries a sentence of up to ten years in prison. 18 U.S.C. $\$ 2319(b)(2)$. By contrast, a Justice Department study in the 1990s found that the average prison sentence for rape was 11.8 years, but those convicted of rape served an average of only 5.4 years in prison. http://bjs.ojp.usdoj.gov/content/pub/pdf/PSATSFV.PDF. Of course, the fact that a copyright infringer can be sentenced to ten years in prison doesn't mean he will be.

89 See, e.g., Lemley \& Reese, supra note __; Mark F. Schultz, Reconciling Social Norms and Copyright Law: Strategies for Persuading People to Pay for Recorded Music, 17 J. Intell. Prop. L. 59 (2009) (discussing these suits). 
access to the lawyers and venture capitalists who supported those intermediaries. ${ }^{90}$ They even sought to change the basic nature of the Internet itself, seizing entire Internet domains and proposing legislation that would have prevented Internet sites from connecting to each other. ${ }^{91}$ It didn't work. Copyright infringement remains rampant on the Internet. The reason is simple: the democratization of content distribution. ${ }^{92}$ The content industry sued tens of thousands of file sharers, and may well have deterred those it sued, but there were tens of millions of people sharing files. It persuaded the government to seize thousands of Internet domains, but many more were beyond the government's reach. ${ }^{93}$ It sued and shut down dozens of software providers, but there were always more who stepped in to take their place.

90 Lemley \& Reese, supra note _, at 1346-47, wrote:

[C]opyright owners have mostly sued direct facilitators like Napster; makers of software that can be used to share files; those who provide tools to crack encryption that protects copyrighted works, providers of search engines that help people find infringing material; "quasi internet service providers" such as universities, eBay, and Yahoo!

Auction; and even credit card companies that help individuals pay for infringing activity. And that was in 2004; many more suits against facilitators have been filed since that time.

91 The government has seized hundreds of domain names in the United States, effectively shutting down entire web sites. See John Blevins, Uncertainty as Enforcement Mechanism: The New Expansion of Secondary Copyright Liability to Internet Platforms, 34 Cardozo L. Rev. 1821 (2013); Karen Kopel, Operation Seizing Our Sites: How the Federal Government Is Taking Domain Names Without Prior Notice, 28 Berkeley Tech. L.J. 529 (2013). Legislative proposals in 2011 and 2012 would have gone further, allowing the government to block legitimate web sites from passing Internet traffic through to sites on a blacklist. See Mark A. Lemley, David S. Levine, \& David Post, Don't Break the Internet, 64 Stan. L. Rev. Online 34 (2011).

92 See, e.g., Rebecca Giblin, The P2P Wars: How Code Beat Law, IEEE Internet Computing, May/June 2012 , at $92-94$.

93 Studies of the shutdown of Megaupload, which at its height accounted for as much as $4 \%$ of global Internet traffic, and the blocking of The Pirate Bay in some countries show that those efforts had only a minor and temporary effect on Internet piracy. See, e.g., Joost Poort et al., Baywatch: Two Approaches to Measure the Effects of Blocking Access to The Pirate Bay (working paper Aug. 22, 2013); Kevin Fogarty, Megaupload Takedown Didn't Slow Pirate Downloads, Just Moved Them Offshore, IT World, Feb. 7, 2012, http://www.itworld.com/security/247998/megaupload-takedown-didnt-slow-piratedownloads-just-moved-them-offshore?utm source=dlvr.it\&utm medium=twitter. But see Brett Danaher \& Michael D. Smith, Gone in 60 Seconds: The Impact of the Megaupload Shutdown on Movie Sales, available at http://papers.ssrn.com/sol3/papers.cfm?abstract id=2229349 (finding that while piracy may not have declined, lawful movie sales increased after the Megaupload shutdown in countries with higher Megaupload usage). 
And while it is possible that some of the more draconian measures the content industry has tried - suing the people who provide Internet service, or passing legislation to prevent interconnection altogether - would have eliminated that democratization, those measures have so far failed, simply because they would destroy so much social value along with reducing copyright infringement. The result was that as marginal costs for online content declined to zero, prices too dropped to zero - first for pirated content, but increasingly for legitimate content. $^{94}$

The result according to IP theory is predictable: with rampant infringement and no effective way to block it, the Internet should have dramatically weakened the incentive to create new content. But the Internet carries a surprising lesson for IP theory. Despite the prevalence of infringement and the teachings of IP theory, people are creating and distributing more content now than ever before, by at least an order of magnitude. ${ }^{95}$ Economic scholarship suggests that while recording industry revenues have declined substantially from their high in $1999,{ }^{96}$ there are more songs being released than ever before, more new artists than ever before, and more purchases of music than ever before, and the songs released are of at least as

94 See, e.g., Jon M. Newman, Copyright Freeconomics, 66 Vand. L. Rev. 1409, 1411-12, 1437 (2013) ("Today, the array of legitimate, 'professional' content that is accessible at zero or negligible prices is truly incredible."); Greg Lastowka, Digital Attribution: Copyright and the Right to Credit, 87 B.U. L. Rev. 41, 54-55 (2007).

95 Rifkin, supra note _ , at 21 (observing that collaborative creation on the Internet, 3D printing, and other new tools has produced "a surge in creativity that is at least equal to the great innovative thrusts experienced by the capitalist market economy in the twentieth century.").

96 Lunney, supra note _ , at 2 (reporting that sales dropped from $\$ 20$ billion to $\$ 7$ billion per year). The 1999 number was itself much higher than the long-run average, reflecting not only a boom economy but people replacing vinyl records and cassette tapes with CDs. See id. at 31 Fig. 1 . Cf. Bart Cammaerts et al., Copyright \& Creation: A Case for Promoting Inclusive Online Sharing 7 (working paper 2013) (finding that while revenue from recorded music dropped substantially from 1998 to 2011, overall revenue in the music industry actually grew during that period). 
high quality as before the Internet. ${ }^{97}$ The rise of sites like YouTube has led to an astonishing outpouring of videos from outside Hollywood, to such an extent that more than 100 hours of new content is uploaded to YouTube every minute; ${ }^{98}$ more content is added to YouTube every month than the major TV networks created in sixty years. ${ }^{99}$ At the same time, the movie industry is faring better than ever before in history, with revenues at an all-time high and more movies being released. ${ }^{100}$ People are buying more books than ever before, thanks in substantial part to Internet downloads. And while the price of those books has declined somewhat, writers are also publishing more books than ever before, including a surprising number of successful self-published books. ${ }^{101}$ And despite piracy, both the film and publishing industries reported higher profit margins in 2012 than they did a decade before. ${ }^{102}$

Perhaps most surprising, people are creating an astonishing array of content specifically for the purpose of giving it away for free on the Internet. Early on, scholars worried that no one

97 See, e.g., Joel Waldfogel, Copyright Protection, Technological Change, and the Quality of New Products: Evidence from Recorded Music Since Napster, 55 J. L. \& Econ. 715 (2012) (studying the quality of music released since file sharing began); Lunney, supra note _, at 2 (reporting that the number of albums released rose from 38,900 in 1999 to 76,875 in 2011, and that more new artists broke into the top fifty songs after file sharing than before). The fact that revenues are declining can coexist with the fact that more people are purchasing music because people used to buy music in bundles called albums, and now primarily buy individual songs.

98 http://youtube-global.blogspot.com/2013/05/heres-to-eight-great-years.html.

99 Statistics, YouTube, http://www.youtube.com/t/press_statistics.

100 Felix Oerholzer-Gee \& Koleman Strumpf, File Sharing and Copyright (2009), available at http://www.hbs.edu/research/pdf/09-132.pdf (finding a substantial increase in movie production since file sharing began).

101 Id. (finding a substantial increase in book publishing since file sharing began); Joel Waldfogel \& ImkeReimers, Storming the Gatekeepers: Digital Disintermediation in the Market for Books, available at http://teasandbooks.wordpress.com/2013/03/13/storming-the-gatekeepers-digital-disintermediationin-the-market-for-books/ (finding that more books are published now than ever before, and a majority of all books and many of the best-selling ones are now self-published).

102 See, e.g., Jonathan Band \& Jonathan Gerafi, Profitability of Copyright-Intensive Industries 3 (2013). 
would create content for the Internet because they couldn't see a way to get paid. ${ }^{103}$ But it is hard to think of a prediction in all of history that has been more dramatically wrong. People spend hundreds of millions of hours a year - likely billions - creating content online for no reason other than to share it with the world. They create and edit Wikipedia pages, post favorite recipes, create guides to TV shows and video games, review stores and restaurants, and post information on literally any subject you can imagine. ${ }^{104}$ If, as Doctor Johnson famously suggested, "no one but a blockhead ever wrote except for money,"105 we are a world of blockheads, gleefully creating and sharing all sorts of content with the world.

Why are people creating so much content without the incentive of IP rights? And why hasn't the sky fallen on the content industries? There are at least six reasons. The first is the very reduction in reproduction and distribution cost that created the infringement problem in the first place. Twenty years ago, most of the cost associated with generating content came not from paying artists to create. Indeed, as noted above, artists normally got only a small fraction of the sales price of their work. The Internet makes most of that cost disappear. As a result, content owners can charge a much lower price online and still be profitable. An ebook may retail for quite a bit less than a hardcover book, but it also costs a lot less to produce.

103 See, e.g., Jane C. Ginsburg, Putting Cars on the "Information Superhighway": Authors, Exploiters, and Copyright in Cyberspace, 95 Colum. L. Rev. 1466, 1467 (1995) ("one can build the highway, but it does not follow that the cars will choose to come. Unless they can become author-friendly, digital media may remain just that: media, without content.").

104 See, e.g., Yochai Benkler, The Wealth of Networks: How Social Production Transforms Markets and Freedom 5-6 (2006) (discussing social production of web sites like Wikipedia and other Internet content); Yochai Benkler, Freedom in the Commons: Toward a Political Economy of Information, 52 Duke L.J. 1245 (2003). The challenge posed to copyright by collective production sites like Wikipedia is not just one of the need for incentives. Collective production challenges the whole concept of authorship. See Matthew Rimmer, Wikipedia, Collective Authorship and the Politics of Knowledge, in Intellectual Property Policy Reform 178 Arum \& van Caenegem eds. 2009).

105 Johnsoniana: Life, Opinions, and Table-Talk of Doctor Johnson 310 (R.W. Montagu ed., Alfred Boot \& Sons: London, 1884). 
Alternatively, content companies may decide (as the music industry has) to jack up their profit margins on digital content by charging the same price online as they would offline. If they do that, they will make fewer sales, but they will make more profit on the sales they do make, since they don't have to pay much for reproduction and distribution of that content.

Companies that take this strategy can remain profitable even with a much higher level of piracy, simply because their costs have declined so dramatically.

Second, "fewer sales" does not mean "no sales." One of the lessons of the Internet is that a surprising number of people will pay for content they like even when they don't have to. ${ }^{106}$ While the increased efficiency of the Internet has driven marginal cost towards zero, there are still many purchases of digital content. For example, people made more music purchases in 2010 than they ever did before the Internet, whether because it is more convenient, because it is legal, or because people actually like supporting musicians they like. ${ }^{107}$ Indeed, the fact that music is available illegally for free may encourage people to try more music, and many of those people then end up paying for music they like. ${ }^{108}$ Even those creators

106 See, e.g., Tobias Regner, Why Consumers Pay Voluntarily: Evidence From Online Music, http://ideas.repec.org/p/irp/irpwrp/2010-081.html (a study on suggested prices that suggests people are strongly influenced by social norms to pay a suggested price).

107 See David Gerard, Culture Is Not About Aesthetics. Punk Rock is Now Enforced By Law, Rocknerd, Sept. 13, 2013, http://rocknerd.co.uk/2013/09/13/culture-is-not-about-aesthetics-punk-rock-is-nowenforced-by-law/ ("I was actually surprised iTunes works at all, ever, for anyone - people paying \$1 for something of zero marginal cost. Every sale is made because the people wanted to pay for the unit in question. Convenience is worth more than l'd thought.").

The rise of streaming services like Spotify changes this calculus somewhat, as consumers switch from buying songs to paying a monthly fee for access to unlimited music. But it does not change the fact that people are paying for music, just the way in which they are doing so (and the rights that come along with it).

108 See, e.g., Ram D. Gopal \& Sudip Bhattacharjee, Do Artists Benefit from Online Music Sharing?, $79 \mathrm{~J}$. Bus. 1503 (2006) (finding that sampling among students leads to greater purchases of authorized copies); Felix Oberholzer-Gee \& Koleman Strumpf, The Effect of File Sharing on Record Sales: An Empirical Analysis, $115 \mathrm{~J}$. Pol. Econ. _ (2007) (finding that illegal downloading did not cut into music 
who depend on copyright revenues for incentives don't need to make money from every copy.

A hybrid ecosystem in which sales coexist with piracy may provide sufficient incentive to keep those artists creating, even if they make less money than they would in a world without piracy. Artists are also finding new (or sometimes old) ways to get paid, from musicians touring and selling T-shirts to writers turning to serialized content. ${ }^{109}$ And offering content to others for free radically expands the number of consumers of that content by eliminating financial transactions, enhancing social welfare. ${ }^{110}$

Third, many of the same technologies that have reduced the cost of reproduction and distribution of content have also reduced the cost of producing that content. High quality music recording no longer requires a trip to a sound studio in Hollywood or Nashville; online tools can enable emerging artists to produce a professional recording at a fraction of the previous cost. ${ }^{111}$ Producing videos is no longer the province of professionals; most people now carry a sophisticated video camera in their pockets, and video production tools enable amateurs to make at least medium-quality video content quickly and cheaply. ${ }^{112}$ Digital technologies have similarly reduced the cost and complexity of photography and the ease of

sales); cf. George Barker \& Tim Maloney, The Impact of Free Music Downloads on the Purchase of Music CDs in Canada (working paper 2012), available at http://ssrn.com/abstract=2128054 (finding that less than one download in twenty substitutes for a music sale).

109 See, e.g., David Streitfeld, Web Fiction, Serialized and Social, N.Y. Times, Mar. 24, 2014, at B1.

110 Economic research suggests that zero is not simply a price like any other; people behave differently when faced with free things. See, e.g., Dan Ariely, Predictably Irrational: The Hidden Forces That Shape Our Decisions 55-72 (2008); Newman, supra note _, at 1444 ("utility does not map linearly onto prices; rather, the positive affect [sic] associated with zero prices causes an outsized increase in valuation as indicated by consumers' revealed preferences."); Kristina Shampan'er et al., Zero as a Special Price: The True Value of Free Products, 26 Marketing Sci. 742, 742 (2007).

111 See Lunney, supra note _ (noting that digital technologies have "radically reduced the costs and risks associated with the production of new music and the introduction of new artists. Instead of expensive studio and production time, we can now use inexpensive software on a home computer.") 112 See, e.g., Michael Kolowich, Three Simple Strategies to Tame Your Video Content Budget, Jan. 30, 2012, available at http://contentmarketinginstitute.com/2012/01/reduce-your-video-content-budget/. 
generating original content on the web in the form of blogs and other web sites. If the cost of creation drops alongside the cost of distribution, IP theory should worry less about the latter.

Fourth, the combination of reduction in the cost of creation and reduction in the cost of reproduction and distribution has opened the doors to numerous new creators who could not find an audience in the pre-Internet world, either because creation was too costly or because they were not identified by the content-distributing intermediaries like record companies, publishing houses, or movie studios. Even if traditional content creators had less incentive to create after the development of the Internet, the Internet enabled the rise of a mass of amateur, semi-professional, and small-scale professional creators that more than made up for the difference. ${ }^{113}$ Chris Anderson refers to this as the "long tail" - a vast multitude of works that are not hits, but which collectively are consumed by more people than blockbuster content. ${ }^{114}$ Notably, a major study by Peter DiCola finds that professional musicians make very little of their money from copyright; over $3 / 4$ of it comes from sources unrelated to copyright. Only composers who do not also perform make most of their money from copyright-related sources. ${ }^{115}$ Kate Darling finds something similar in adult entertainment, where some losses

113 For a discussion of new kinds of production these trends enable, such as networked collaboration and peer production, see, e.g., Benkler, supra note _; Julie E. Cohen, Copyright as Property in the PostIndustrial Economy: A Research Agenda, 2011 Wis. L. Rev. 141.

114 Chris Anderson, The Long Tail: Why the Future of Business is Selling Less for More (2006).

115 Peter DiCola, Money From Music: Survey Evidence on Musicians' Revenue and Lessons About Copyright Incentives, 55 Ariz. L. Rev. 301, 304-05 (2013); see also Martin Kretschmer, Does Copyright Law Matter? An Empirical Analysis of Creators' Earnings (2012), available at http://ssrn.com/abstract=2063735 (finding that most copyright revenues go to a few superstars). It is possible that creators create in hopes of being one of the few superstars whose work is actually rewarded by copyright law. It is well known that people systematically overvalue the prospect of a large but unlikely reward; that's why they buy lottery tickets. Some scholars have suggested that the same effect may be at work in IP. Mark A. Lemley, What's Different About Intellectual Property?, 83 Tex. L. Rev. 1095 (2005); Dennis D. Crouch, The Patent Lottery: Exploiting Behavioral Economics for the Common Good, 16 Geo. Mason L. Rev. 141 (2008); F.M. Scherer, The Innovation Lottery, in Expanding 
from widespread piracy were more than made up for by the entry of new content providers as the cost of photo and video production technology dropped precipitously. ${ }^{116}$ And studies by Eric von Hippel have found that even before the Internet, the amount of amateur user innovation dwarfs that by professional research and development facilities. ${ }^{117}$ He argues that technology permits more and more democratization of innovation. ${ }^{118}$ If the goal of IP is to encourage new creation, the fact that we have opened new avenues to implement and distribute that creativity may serve that goal even as traditional paid content creation jobs decline. When it comes to creation, the evidence suggests that we want many different eyes on a problem, not just one or two people, no matter how concentrated their incentives. ${ }^{119}$ Fifth, opening the door to new creators by reducing costs and barriers to entry doesn't just give us the new works those creators make; it may actually encourage creativity by others. A growing body of economic literature finds that "spillovers" - third-party benefits provided by a work that its creator can't capture - actually drive further innovation. ${ }^{120}$ Being around people with good ideas, whether geographically or in product space, actually makes it more likely you

the Boundaries of Intellectual Property: Innovation Policy for the Knowledge Society 3, 3 (Rochelle Cooper Dreyfuss et al. eds., 2001). But if so, the incentive on which we rely is, as Kretschmer puts it, "based on a systematic cognitive mistake." Kretschmer, supra, at 1 . In effect, we are coaxing works out of these creators by lying to them about their chances of getting paid.

116 See, e.g., Kate Darling, What Drives IP Without IP? A Study of the Online Adult Entertainment Industry (working paper 2013), available at http://papers.ssrn.com/sol3/papers.cfm?abstract id=2198934.

117 See, e.g., Eric von Hippel et al., Comparing Business and Household Sector Innovation in Consumer Products: Findings from a Representative Study in the UK (working paper 2011), available at http://ssrn.com/abstract=1683503.

118 Eric von Hippel, Democratizing Innovation (2005).

119 See, e.g., Ken Arrow, The Economics of Information (1984); Orly Lobel, Talent Wants to be Free 9 (2014) ("movement and competition are good for innovation.").

120 See, e.g., Brett M. Frischmann \& Mark A. Lemley, Spillovers, 107 Colum. L. Rev. 257 (2007). 
will have good ideas of your own. ${ }^{121}$ So opening up creativity to newcomers may actually make existing creators more productive.

Finally, it may simply be that IP theory is wrong about what motivates people to create.

There is substantial evidence in the innovation and psychology literatures that motivation to create is largely internal and/or problem driven. ${ }^{122}$ People create because they have an inspiration, because they are driven to do so, or because they want to solve a problem. ${ }^{123}$ They seem to be motivated more by rights of attribution and recognition than by money. ${ }^{124}$ Free

121 See id. at 259-61 and sources cited therein; Lobel, supra note _, at 9 ("a touchstone of talent mobility is the interaction between inventive people. New data continue to reveal that when innovators collaborate they become greater than the sum of their parts.").

122 For a discussion of the neuroscience of creativity, see Jonah Lehrer, Imagine: How Creativity Works (2012); Erez Reuveni, Copyright, Neuroscience, and Creativity, 64 Ala. L. Rev. _ (2013); Lobel, supra note _, at 170-79.

123 The literature on this in IP is recent but growing. See, e.g., Chander \& Sunder, supra note _, at 1402-03; Julie E. Cohen, Creativity and Culture in Copyright Theory, 40 U.C. Davis L. Rev. 1151 (2007); Jeanne C. Fromer, A Psychology of Intellectual Property, 104 Nw. U. L. Rev. 1441, 1443-44 (2010); Eric E. Johnson, Intellectual Property and the Incentive Fallacy, 39 Fla. St. U. L. Rev. 623, 627 (2012); Gregory N. Mandel, Left-Brain Versus Right-Brain: Competing Conceptions of Creativity in Intellectual Property Law, 44 U.C. Davis L. Rev. 283, 285-86 (2010); Gregory N. Mandel, To Promote the Creative Process: Intellectual Property Law and the Psychology of Creativity, 86 Notre Dame L. Rev. 1999 (2011); Jessica Silbey, Harvesting Intellectual Property: Inspired Beginnings and "Work-Makes-Work": Two Stages in the Creative Process of Artists and Innovators, 86 Notre Dame L. Rev. 2091 (2011); Sara K. Stadler, Incentive and Expectation in Copyright, 58 Hastings L.J. 433 (2007); Rebecca Tushnet, Economies of Desire: Fair Use and Marketplace Assumptions, 51 Wm. \& Mary L. Rev. 513, 515 (2009); Diane Leenheer Zimmerman, Copyright as Incentives: Did We Just Imagine That?, 12 Theoretical Inquiries in L. 29 (2011). But see Ouellette, Prizes, supra note _ (challenging the evidence behind the idea that creation is driven by nonmonetary motivations). Cf. Laura Pedraza-Farina, Patent Law and the Sociology of Innovation, 2013 Wis. L. Rev. 813 (documenting the various sociological factors that play into scientific discovery and how quickly that discovery is accepted).

One might view the idea that creators aren't primarily motivated by money as a rejection of economics, but I don't think it is. Economics, properly understood, is about understanding the incentives that motivate human behavior. Sometimes that is money, but not always. Evidence that people are motivated to create by things other than money may mean the classic IP incentive story is wrong, but it doesn't mean that economics is wrong.

124 Mihaly Csikszentmihalyi, Creativity 107-08 (1996); Jessica Silbey, The Eureka Myth: Creators, Innovators, and Everyday Intellectual Property (forthcoming 2015) (surveying creators about their motivations); Jeanne C. Fromer, Expressive Incentives in Intellectual Property, 98 Va. L. Rev. 1745, 1777 (2012) ("creators' beliefs in their moral rights typically seem to dominate their pecuniary interests in 
riding doesn't seem to stop them from innovating. ${ }^{125}$ Indeed, there is even evidence that monetary incentives can reduce creativity: works created because of a demand or promise of payment are less creative than those created for other reasons, because "doing it for the money" seems to dampen intrinsic motivation. ${ }^{126}$ And the way they create seems to rely on networks of people and information that creators draw on as inputs. ${ }^{127}$ Collaboration may be inherently more productive than the isolated work economic self-interest would seem to dictate. ${ }^{128}$ If so, the Internet may have spurred an unprecedented outpouring of creativity for the simple reason that many people are now free to create and share their works with the world for the first time ever. More input plus more minds at work means more creative works.

creating"); Fromer, supra note _, at 1483; William Hubbard, Inventing Norms, 44 Conn. L. Rev. 369 (2011); Rebecca Tushnet, Naming Rights: Attribution and Law, 2007 Utah L. Rev. 789.

125 See, e.g., Christoph Engel \& Marco Kleine, Who Is Afraid of Pirates? An Experiment on the Deterrence of Innovation by Imitation (working paper 2013), available at http://ssrn.com/abstract=2269635 (finding in an experimental study that there is more imitation than expected, but that that imitation does not deter innovation).

126 Teresa Amabile, Creativity in Context 33 (1996); Mandel, Promote, supra note _, at 2010 ("As motivation moves from the extrinsic toward the intrinsic side of the motivation spectrum, individuals' work product tends to become more creative."); Lobel, supra note _, at 190-95; John Quiggin \& Dan Hunter, Money Ruins Everything, 30 Hastings Comm. \& Ent. L.J. 203, 214-15 (2008); Beth A. Hennessey \& Teresa M. Amabile, Reward, Intrinsic Motivation, and Creativity 53 Am. Psychologist 674 (1998). For an empirical test of this question, see Christopher Buccafusco et al., Empirical Studies of Incentives in Intellectual Property (working paper 2014); cf. Yuval Feldman \& Orly Lobel, The Incentives Matrix: The Comparative Effectiveness of Rewards, Liabilities, Duties, and Protections for Reporting Illegality, 87 Tex. L. Rev. _ (2010).

There is another factor at work here - people in any occupation work less as they are paid more, because they substitute leisure time for additional money. That is true of creators as well as other kinds of employees. Thus, Mike Scherer finds that Italian composer Giuseppi Verdi substantially reduced the number of operas he wrote each decade once copyright was introduced in Italy and his earnings increased. F.M. Scherer, The Emergence of Musical Copyright in Europe from 1709 to 1850, 2 Rev. Econ. Res. Copyright Issues 3, 11 (2008). Lunney makes this point more general - beyond a certain point, artists will create less as they are paid more. Lunney, supra note _, at 16-18. That is particularly true with copyright, which provides a continuing revenue stream for past works rather than conditioning payment on future creativity.

127 Reuveni, supra note _, at [Part III].

128 See Yochai Benkler, The Penguin and the Leviathan: How Cooperation Triumphs Over Self-Interest (2011). 
This last hypothesis, if true, does not mean that IP never played a role in the creative process, or that it cannot continue to do so in some ways. It may be that even if artists and inventors are not primarily motivated by money, corporations are. ${ }^{129}$ Those corporations might pay the artists and inventors to create, or acquire their work and do the costly job of bringing it to the masses. A number of scholars have suggested that what IP truly encourages is not the act of creation but the act of commercialization. ${ }^{130}$ I have elsewhere been critical of the idea that we should give one company control over investing in bringing a product to market. ${ }^{131}$ And the empirical evidence suggests that IP rights actually impede rather than encourage commercialization. ${ }^{132}$ But even those who believe that IP law traditionally served the goal not

129 Julie Cohen suggests that IP is fundamentally about generating property rights for corporations, not creators. Cohen, supra note _, at _.

130 Michael Abramowicz, The Danger of Underdeveloped Patent Prospects, 92 Cornell L. Rev. 1065 (2007); F. Scott Kieff, Property Rights and Property Rules for Commercializing Inventions, 85 Minn. L. Rev. 697 (2001); Michael Abramowicz \& John F. Duffy, Intellectual Property for Market Experimentation, 83 N.Y.U. L. Rev. 337 (2008); Ted Sichelman, Commercializing Patents, 62 Stan. L. Rev. 341, 345 (2010); Jonathan Barnett, Copyright Without Creators (working paper 2013).

131 Mark A. Lemley, The Myth of the Sole Inventor, 110 Mich. L. Rev. 709 (2012); Mark A. Lemley, Ex Ante Versus Ex Post Justifications for Intellectual Property, 71 U. Chi. L. Rev. 129 (2004). There is good empirical evidence that patent rights do not drive technology transfer and may in fact impede it. See, e.g., Rochelle Cooper Dreyfuss, Double or Nothing: Technology Transfer Under the Bayh-Dole Act, in Business Innovation and the Law 52, 61-62 (2013); Secretary's Advisory Commission on Genetics, Health, and Society, Gene Patents and Licensing Practices and their Impact on Patient Access to Genetic Tests (2010), available at http://oba.od.nih.gov/oba/sachgs/reports/SACHGS patents report 2010.pdf (finding that patent owners on medical diagnostic tests were never the first to market with those tests); Heidi L. Williams, Intellectual Property Rights and Innovation: Evidence from the Human Genome (working paper 2010), available at http://www.nber.org/papers/w16213 (finding that products based on genetic data in public databases were more likely to be commercialized than products based on proprietary databases); Bhaven Sampat \& Heidi Williams, How Do Patents Affect Follow-on Innovation? Evidence from the Assignment of Patent Applications to Patent Examiners (working paper 2014) (finding no significant value to patents in driving ex-post commercialization, even in biotechnology). $C f$. Michael J. Burstein, Exchanging Information Without Intellectual Property, 91 Tex. L. Rev. 227 (2012) (arguing that IP is not necessary for commercialization in many circumstances).

132 See, e.g., Paul J. Heald, How Copyright Makes Books and Music Disappear (and How Secondary Liability Rules Help Resurrect Old Songs (working paper 2013) (finding in an empirical study that "[t]ogether with publishing business models, copyright law seems to stifle distribution and access."); 
of encouraging creation but of encouraging its distribution should acknowledge that the Internet renders that justification irrelevant. An IP regime based on the idea that reproduction and distribution are costly and need to be encouraged becomes unnecessary in a world where reproduction and distribution become costless.

Related justifications focus on the value of the commercializer as intermediary, picking the valuable books and songs so the consumer doesn't have to. Jonathan Barnett, for example, argues that while the Internet reduces costs of creation, reproduction and distribution, it increases the costs of finding and evaluating that content. ${ }^{133}$ He argues that copyright owners are necessary to pick future superstars for us. ${ }^{134}$ Patent theory has similarly focused on the role of patents as signaling devices. ${ }^{135}$ But that justification too collapses with the arrival of the Internet, since crowds do a surprisingly good job of picking the content they want. Indeed, in some modern content markets it is crowds that perform the intermediation function, with the content industries publishing works only after they have been pre-selected by the audience. For example, Joel Waldfogel and Imke Reimers show that an astonishing $10 \%$ of best-selling books were first self-published, and that in some popular genres that percentage is over $30 \%$; they got mainstream publishers only after they proved their value in the marketplace. ${ }^{136}$ Similarly, many superstars in music and even television were relative unknowns disdained by

Paul J. Heald, Property Rights and the Efficient Exploitation of Copyrighted Works: An Empirical Analysis of Public Domain and Copyrighted Fiction Bestsellers, 92 Minn. L. Rev. 1031 (2008).

133 Barnett, supra note _, at 39.

134 Id. at 42-44.

135 Clarisa Long, Patent Signals, 69 U. Chi. L. Rev. 625 (2002); Mark A. Lemley, Reconceiving Patents in the Age of Venture Capital, 4 J. Sm. \& Emerging Bus. L. 137 (2000).

136 Waldfogel \& Reimers, supra note _, at _. 
the major studios but discovered by fans, including Justin Bieber. ${ }^{137}$ And even if crowds can't be relied upon to pick books, music, and movies, software is getting better and better at doing it for us as artificial intelligence improves and as Big Data gives it more detailed information about our likes and dislikes. ${ }^{138}$

There is still a role for IP on the Internet. There are some works that are so costly to create even in the digital world that they are unlikely to be made without effective IP protection. Big-budget movies and video games cost hundreds of millions of dollars to make. No amount of creative fire will drive someone who doesn't have hundreds of millions of dollars to make Peter Jackson's Lord of the Rings trilogy. They need corporate backing, and the corporate backers need a revenue stream. But in the Internet era those works are increasingly the exception, not the rule. And the law therefore needs to figure out ways to protect those exceptional works without blocking the creativity that is happening despite, not because of, IP.

\section{B. Lessons from the Internet Experience}

The Internet offers valuable lessons for the coming economy of plenty. In a world where goods, services, and biologics share the economic characteristics of the Internet, what can we learn about IP and innovation in those spaces? Here are several lessons.

\section{IP Owners Will Fight the Death of Scarcity}

137 OK, bad example. See Joel Waldfogel, And the Bands Played On: Digital Disintermediation and the Quality of New Recorded Music (2012), available at http://ssrn.com/abstract=2117372 (finding that independently produced albums that would not have made it to market under a pre-Internet regime account for a growing share of commercially successful albums).

138 See Rifkin, supra note _, at 130. 
Content owners fought tooth and nail to prevent the development of digital content.

They sought to shut down the technology, to sue the people who used it, and to sue anyone associated with those people. Ironically, at least one reason copyright infringement is so prevalent on the Internet is that for many years consumers who wanted access to digital content on demand had no legal alternative. The music industry spent years trying to shut down digital music before actually offering a realistic legal digital music service. And when they finally did offer a legal alternative, iTunes, they priced their songs to protect their offline music market rather than to make digital music attractive. Book publishers conspired to raise the price of ebooks so they wouldn't cut into the sales of hardback books; it took a successful government antitrust case to force competition in ebook pricing. ${ }^{139}$ And even today the labyrinth of rules around lawful access to television shows is so great that it is impossible to know what episodes of a show will be available when, from what source, and for how long. ${ }^{140}$ Some of that resistance is irrational - a fear that the sky is falling whenever things change. But some of it is rational even if not socially optimal. While I suggested in the last part that society would benefit from the explosion of content on the Internet, and I think that on balance creators will too, it does not follow that existing copyright industries will benefit. The history of technological disruption of copyright law is almost always one of more people creating more content and making more money, ${ }^{141}$ but the people making money from content in the new regime are not always the same ones who made money in the old. The phonograph

\footnotetext{
139 United States v. Apple, Inc., 952 F. Supp. 2d 638 (S.D.N.Y. 2013).

140 This problem has even been mocked in a cartoon. http://theoatmeal.com/comics/game of thrones (detailing the adventures of someone who tries and fails to watch Game of Thrones legally on the Internet). [Warning: as with most of the Oatmeal cartoons, this one is NSFW].

141 Lemley, Sky Falling, supra note _.
} 
was a godsend to both musicians and consumers, but those in the business of printing sheet music probably didn't see it that way. Similarly, while record companies, movie studios, and book publishers will all likely survive the digital transition, it is doubtful they will be able to hold onto a business model in which they take the lion's share of the revenue, leaving only a small percentage for the artists. It may well be rational for record companies and movie studios to fight the digital transition, even if it is rational for everyone else concerned to hope they lose that fight. $^{142}$

The same dynamic is likely to play out in each of the new technologies I discussed in Part I. Professional industrial design firms will resist having their works "Napsterized" ${ }^{143}$ because they fear losing control over who can use their design and not getting paid when people do. ${ }^{144}$ Indeed, some have already called for strengthening IP laws to try to block the distribution of designs for patented products to 3D printers. ${ }^{145}$ Large biotechnology companies will resist the move to a modular, open-source synthetic biology. And while the economics are less clear, robotics companies may well resist giving control over what their robots do to a host of

142 See Rifkin, supra note __, at 6 ("Powerful industry leaders often strive to restrict entry of new enterprises and innovations."); Mark P. McKenna, Fixing Copyright in Three Impossible Steps, 39 J. Coll. \& Univ. L. 715, 726 (2013) ("It is, of course, inevitable that economic interests will harden around existing rules and technologies. But that is all the more reason to be skeptical of claims by rights owners that new technologies threaten creativity - what they really mean is that those new technologies threaten certain entrenched interests.").

${ }_{143}$ Desai \& Magliocca, supra note _, at _.

144 See Finocchiaro, supra note _, at 507-08 (noting the risk that incumbents will seek to regulate 3D printing to protect their own interests); Desai \& Magliocca, supra note _, at 27 ["The temptation to lobby for legal limits on 3D printing technology will be strong").

145 See, e.g., Nicole A. Syzdek, Five Stages of Patent Grief to Achieve 3D Printing Acceptance 11, 12 (working paper 2014) ("Initially it may be easy for enraged patent holders to persuade policy makers and judges to impose limits on the growth of 3D printing technology... Patent holders may [also] try to teach the public about the illegality of infringement through litigation."). Notably, Syzdek does not support these efforts to stifle the technology.

Futurist Cory Doctorow published a book in 2006 premised on the idea that governments banned 3D printers because of their potential for illegal use. Cory Doctorow, Printcrime (2006). 
amateurs who can change and upgrade those robots, preferring instead to keep control in the factory (and keep demand for new versions strong). ${ }^{146}$ IP law offers tools to each of those companies: design and utility patents in the case of 3D printing, ${ }^{147}$ utility patents for synthetic biology, and patents and copyrights for robotics. We should expect to hear the same sorts of warnings about these new technologies that we heard about the Internet, and we should expect to see the same effort to use IP rights and the courts to bring those technologies under control.

\section{IP Owners Will (Probably) Lose That Fight}

IP owners lost the fight to keep content off the Internet, or alternatively to lock down the Internet itself, for two reasons. First, there was simply too much value to the Internet as a whole and the digital distribution of content. Courts were willing to shut down sites like Napster, Grokster, and others that they viewed as designed entirely to profit from copyright infringement, ${ }^{148}$ but they have so far balked at IP owner requests to ban sites like Amazon.com, Google or YouTube that clearly had large social value despite also facilitating some infringement. ${ }^{149}$ The second reason has to do with the democratizing nature of the Internet.

\footnotetext{
146 Manufacturers of robots and 3D printers may worry for other reasons as well, such as the risk of liability if their devices are misused. See Engstrom, supra note _ (discussing the difficulties in assessing liability in a world of 3D printing).

147 Patent law has traditionally not applied to the movement or sale of information or blueprints for creating devices rather than the devices themselves. See, e.g., Bayer v. Housey Pharm. Co., 340 F.3d 1367 (Fed. Cir. 2003); Microsoft Corp. v. AT\&T Corp., 550 U.S. 437 (2007). But the International Trade Commission recently ignored that precedent in issuing an order barring the "importation" of digital files describing braces for teeth. In the Matter of Certain Digital Models (ITC 2014).

148 See, e.g., MGM Studios v. Grokster Ltd., 545 U.S. 913 (2005); A\&M Records, Inc. v. Napster, Inc., 239 F.3d 1004 ( $9^{\text {th }}$ Cir. 2001).

149 See, e.g., Field v. Google Inc., 412 F. Supp. 2d 1106 (D. Nev. 2006); Perfect 10, Inc. v. Amazon.com, Inc., 508 F.3d 1146 ( $9^{\text {th }}$ Cir. 2007); Viacom v. YouTube, 676 F.3d 19 (2d Cir. 2012).
} 
There is no central infringer on the Internet. When centralized nodes for specialized services did appear, like Napster, courts promptly shut them down. But because there was so much demand for content online, even when sites were shut down others promptly took their place. And those sites became more and more decentralized, and correspondingly harder and harder to shut down. ${ }^{150}$ IP owners were reduced to playing Whack-a-Mole with infringing sites.

The same dynamic is likely to unfold with each of the three technologies I discuss in this paper. We have already seen calls to ban content on 3D printers - not because of IP infringement, but because people have distributed blueprints for 3D printing plastic guns that can bypass traditional airport security. ${ }^{151}$ But precisely because the blueprint for the 3Dprinted gun is nothing more than information, it turns out to be extremely hard to suppress it. IP owners are likely to run into the same sorts of obstacles in suppressing patented designs, code for robots, and genetic sequences distributed on the Internet.

IP owners in each of those industries may well turn, as the content industries did, to an effort to shut down or regulate the new technology altogether. Lawmakers frustrated by 3Dprinted guns have already begun to talk about regulating the sale of 3D printers themselves, just as copyright owners have sought to regulate Internet connections and search engines. It is easy to imagine legislators similarly seeking to regulate gene printers in an effort to stop smallpox or to regulate unauthorized modifications to robots.

150 For instance, Napster was a single, centralized search function for peer-to-peer sharing of mp3 sites. When it was shut down, it was replaced by Grokster and Morpheus, which did not use a central server but relied on "supernodes" run by individual users of the software to distribute content across the peerto-peer network. MGM Studios, Inc. v. Grokster Ltd., 545 U.S. 913 (2005). When Grokster was shut down, $i d$., it was replaced by BitTorrent, which has no centralized nodes at all and relies on individual user computers to pass along small bits of individual files, so that no user is transmitting all or most of a particular work. See http://computer.howstuffworks.com/bittorrent.htm.

151 See, e.g., Engstrom, supra note 
I believe - and hope - that those efforts will fail, for the simple reason that the potential social value in these new technologies, like the Internet, is enormous. But that outcome is not certain. It depends on how established the technologies are when IP owners and others try to ban them, how clear the benefits of those technologies have become, and the farsightedness of courts and legislators asked to restrain innovation in order to protect incumbent businesses. It also depends on the particular characteristics of the IP regimes affected. Copyright law fairly early on built in a limited immunity for intermediaries that allowed the development of distribution technologies like YouTube. ${ }^{152}$ But the IP laws that will apply to 3D printers, synthetic biology, and robotics are not just copyright but also patent and design patent law. And those laws have characteristics that are much less hospitable to intermediaries. Patent and design patent law do not require copying; independent creation of the same technology is an act of infringement. ${ }^{153}$ There is as yet no immunity for intermediaries from patent or design patent infringement. And design patents at least have a draconian damages regime that imposes a disproportionate burden on those found to infringe. ${ }^{154}$ On the other hand, copyright law is more easily adapted to information; depending on the way the claims are written, owners of utility or design patents might have to sue the actual maker of a thing rather than just the intermediary who provides a blueprint. ${ }^{155}$

15215 U.S.C. $\S 1201$.

153 See, e.g., Allen Eng'g Corp. v. Bartell Indus., Inc., 299 F.3d 1336, 1351 (Fed. Cir. 2002) (explaining that copying plays no role in the claim to allegedly infringing product or process comparison); Mark A. Lemley, Should Patent Infringement Require Proof of Copying?, 105 Mich. L. Rev. 1525, 1525 (2007). 15435 U.S.C. §289. For criticism of this rule, see Mark A. Lemley, A Rational System of Design Patent Remedies, 17 Stan. Tech. L. Rev. __ (forthcoming 2014).

155 Brean, supra note _, makes this argument. 
The Internet has survived repeated efforts by private parties to lock it down, and it seems unlikely after the dramatic defeat of SOPA ${ }^{156}$ that anything so draconian will pass, in the United States at least. But that was never a guaranteed outcome. ${ }^{157}$ One possible future for 3D printing, synthetic biology, and robotics is a dystopian one in which a few large companies get the right to decide what sorts of innovation are permissible, whether by combining existing law with ubiquitous surveillance technology or by passing new laws that restrict entry into the technology. That is a particularly worrisome outcome in complex technologies like synthetic biology and robotics, because it is unlikely that any one company is going to be the best at developing all the pieces of the technology someone might want to use. iRobot might make a great vacuum cleaner (the Roomba), but there is no guarantee they will also make the best software for having a robot screen phone calls or wash dishes.

\section{IP Owners' Loss Is (Mostly) Innovation's Success}

If we can avoid the dystopian future of lockdown, the future of technology is likely to look quite a bit like the Internet. Lots of people will create lots of designs, code, and biobricks. Other people will use, repurpose, and improve on those things, often without paying. But people will continue to create, because some people will pay for their creations, because there will be other ways to make money from being creative, because they want to be known for

156 The Stop Online Piracy Act was proposed legislation that would have given courts the power to prevent interconnection on the Internet to web sites deemed to traffic in piracy. It was stopped by an unprecedented coalition of Internet companies and individuals. See David Moon et al., Hacking Politics: How Geeks, Progressives, the Tea Party, Gamers, Anarchists, and Suits Teamed Up to Defeat Sopa and Save the Internet (2013), available at http://www.orbooks.com/catalog/hacking-politics-2/.

157 Nor did the Internet emerge entirely unscathed from the lockdown efforts, as Mike LInksvayer points out. Mike LInksvayer, Innovation Policy in a World With Less Scarcity, http://gondwanaland.com/mlog/2014/03/28/ip-post-scarcity/. 
something or want the feeling of accomplishment that comes with creating, and, ultimately, simply because they can. More and more of these creations will operate outside the IP system, either expressly (biobrick inventors who choose not to patent their inventions, for instance) or by the simple virtue of ignoring that system. ${ }^{158}$

This future is not a utopia. None of the technologies I have described is perfect, and each requires physical inputs that will in turn be subject to the laws of scarcity. Further, the lesson of the Internet is that while cheap, democratized production drives more creation, not less, it may also change the nature of that creation. Without IP rights we may see more creation by amateurs and academics and less by professional creators, just as we now see more new bands and fewer bands with multi-album staying power. ${ }^{159}$ That is both a good and a bad thing; removing the requirement of a major label record contract has let lots of new talent into music, but the decline of professional artists may change the nature of music in ways that cause us to lose some music we'd like to have. Similarly, it is possible to imagine both a wealth of new product designs for 3D printers and a decline in the number of professional design firms. And in synthetic biology, where at least some products are likely to be heavily regulated, the cost and delay associated with that regulation may require some means to recoup investment.

At least in the medium term, however, those professional firms are likely to coexist with the amateurs, just as professional musicians and movie studios have found it possible to coexist - even thrive - alongside the new entrants. Part of the reason is that the dramatic reduction in cost that has spurred new entry also boosted the demand for content - people consume more

158 See von Hippel, Democratizing, supra note _, at 89-91 (noting how the willingness of user innovators to give their ideas away calls into question the basic theory of IP).

159 See supra notes __- and accompanying text. 
music and video content than ever before, for example. Part of the reason is that people are willing to pay for things they like, delivered in a convenient package. And IP rights are unlikely to disappear even if they are increasingly flouted, so professional providers who choose to rely on IP rather than sharing their work for free can still make some money by doing so. ${ }^{160}$

In short, the technologies I highlight in this article offer a world in which people create more things at less cost, largely despite rather than because of the IP laws. The IP laws will continue to exist, and they will provide a necessary incentive for some forms of creativity. But creation that relies on IP is likely to play a less and less significant role in a post-scarcity world.

None of this is to say that these new technologies have no risks. A number of scholars have worried about the health and safety risks of distributed access to technologies that can 3D print guns or, worse, viruses. ${ }^{161}$ Some might conclude that we should regulate these technologies, not in the hopes of encouraging innovation, but in order to prevent innovation that can cause harm to society. ${ }^{162}$ But that is not what IP is supposed to be about. If we want to regulate technologies because of their harmful social effects, IP would seem an odd place to do it.

\section{Beyond the Economics of Scarcity}

160 See Desai \& Magliocca, supra note _, at 27 ("firms would be better off embracing this change in production to cultivate new markets instead of trying to win Pyrrhic victories in Congress and the courts.")

161 See, e.g., Engstrom, supra note __ (discussing the dispute over 3D-printed guns); Jordan Paradise \& Ethan Fitzpatrick, Synthetic Biology: Does Re-Writing Nature Require Re-Writing Regulation?, 117 Penn St. L. Rev. 53 (2012).

162 Gabriella Blum, Big Brother and Little Brother: Technology and the Future of Violence (forthcoming 2014) (arguing for a greater role for government in regulating access to dangerous distributed technologies). 
As we saw in Part II, IP law has significant implications for the development of a number of different technologies. But those technologies also have significant implications for IP law, and indeed for the economy more generally.

\section{A. IP in a Post-Scarcity World}

I suggested in Part II that on the Internet, we increasingly get creativity in spite of, rather than because of, IP law. If true, that fact has important implications for the role of IP. We are still a long way from a post-scarcity world. But as more and more pieces of the economy are based on information coupled with cheap, decentralized supplies of physical goods, our IP rules take on increasing importance. The point of the IP laws is to encourage creation. If those laws are not promoting innovation and creation in that new world, we need to rethink them.

The IP laws were created in a world of scarcity. They sought to take ideas that were public goods - things that by their nature were not scarce - and artificially create scarcity around them by designating them as owned by someone. The hope was that by bringing those ideas within the traditional framework of economics, we would create market incentives we could understand and accordingly encourage investment both in the creation of new things and the distribution of those things to the world. By most accounts that approach has worked quite well for a long time.

But that doesn't mean it always will. IP regimes have always coexisted with areas of innovation not protected by IP, governed instead by open competition or informal norms of 
sharing. Food, fashion, comedy, and many others come to mind. ${ }^{163}$ And as Jessica Litman has noted, we have seen robust innovation environments develop wherever there are limits or exceptions to copyright law. ${ }^{164}$ Even in domains in which IP offered protection, people have chosen to opt out of that protection or change its rules to suit their needs. ${ }^{165}$ The Internet is one such domain; most of the work created for the Internet is nominally copyrighted but in practice subject to norms of nonenforcement under a wide range of conditions. It may be that we simply do not need IP protection when both the cost of creation and the cost of distribution fall below a certain point. If I am right about the trajectory of the technologies I have discussed here, more and more pieces of the economy will fall below that threshold.

That doesn't mean IP can or will disappear, and certainly not overnight. Rather, how much (if any) IP we need in a given industry is a function of the characteristics of that industry.

163 See, e.g., Kal Raustiala \& Christopher Sprigman, The Knockoff Economy (2012); Kal Raustiala \& Christopher Sprigman, The Piracy Paradox: Innovation and Intellectual Property in Fashion Design, 92 Va. L. Rev. 1687 (2006); Dotan Oliar \& Christopher Sprigman, There's No Free Laugh (Anymore): The Emergence of Intellectual Property Norms and the Transformation of Stand-Up Comedy, 94 Va. L. Rev. 1787, 1787-88 (2008); Emmanuelle Fauchart \& Eric von Hippel, Norms-Based Intellectual Property Systems: The Case of French Chefs (MIT Sloan working paper No. 4576-06, 2006); David Fagundes, Talk Derby to Me: Intellectual Property Norms Governing Roller Derby Pseudonyms, 90 Tex. L. Rev. 1093 (2012); Matthew Beasley, Who Owns Your Skin: Intellectual Property and Norms Among Tattoo Artists, 85 S. Cal. L. Rev. 1137 (2012); Aaron Perzanowski, Tattoos and IP Norms, 98 Minn. L. Rev. 511 (2013); Elizabeth L. Rosenblatt, A Theory of IP's Negative Space, 34 Colum. J. L. \& Arts 317 (2011). But see C. Scott Hemphill \& Jeannie Suk, The Law, Culture, and Economics of Fashion, 61 Stan. L. Rev. 1147 (2009) (disputing Raustiala and Sprigman's claim that the lack of IP protection drives innovation in fashion). For criticism of the reliance on informal norms, see Jennifer E. Rothman, The Questionable Use of Custom in Intellectual Property, 93 Va. L. Rev. 1899 (2007). Amy Kapczynski has even explored the role of innovation without IP in high-cost areas like pharmaceuticals. Amy Kapczynski, Order Without Intellectual Property Law: A Case Study in Influenza (working paper 2014).

164 Jessica Litman, Revising Copyright Law for the Information Age, 75 Or. L. Rev. 19 (1996).

165 Benkler, Networks, supra note _; Mark A. Lemley, Intellectual Property Rights and Standard-Setting Organizations, 90 Calif. L. Rev. 1889 (2002); Mark A. Lemley, Contracting Around Liability Rules, 100 Calif. L. Rev. 463 (2012); Robert P. Merges, Contracting Into Liability Rules: Intellectual Property Rights and Collective Rights Organizations, 84 Calif. L. Rev. 1293 (1996); Jonathan M. Barnett, Property as Process: How Innovation Markets Select Innovation Regimes, 119 Yale L.J. 384 (2009); Perzanowski, supra note 
As those characteristics change, so must IP. There are some industries, like pharmaceuticals, that will need strong IP protection for the foreseeable future to compensate for government regulatory barriers. And even in industries that lack those barriers, there may be technologies or creative works (like big-budget movies and video games) that cost so much to develop that no one will invest in them without IP protection. ${ }^{166}$ Further, the technologies I have described won't eliminate all scarcity, and certainly not right away. Rather, market disruption will come in fits and starts as technologies develop and are deployed at differing rates. But in a postscarcity world high-cost products will increasingly become the exception, not the norm. They will be islands of IP-driven content in a sea of content created without the need for IP.

IP is essentially a form of government regulation. The government restricts entry into the market, or alternatively controls the price at which that entry can occur, in order to serve valuable social ends. ${ }^{167}$ But regulation is not a moral entitlement or something that we must take for granted. In the past, government regulated all sorts of industries - railroads, trucking, electric power, gas, telephones - because it could not see given the economics of those industries how a free market could produce socially optimal results. ${ }^{168}$ But in a surprising number of cases, when we deregulated those industries we found that the market could indeed

166 Or perhaps some other form of government subsidy. States and localities in the US spent \$1.4 billion subsidizing films in 2010. Reihan Salam \& Patrick Ruffini, The Internet and Its Enemies, in Copyright Unbalanced: From Incentive to Excess 23, 25 (Jerry Brito ed. 2012). 167 See, e.g., Shubha Ghosh, Decoding and Recoding Natural Monopoly in Intellectual Property, $2008 \mathrm{U}$. III. L. Rev. 1125; Shubha Ghosh, Patents and the Regulatory State: Rethinking the Bargain Metaphor After Eldred, 19 Berkeley Tech. L.J. 1315 (2004); Lemley, Regulatory Turn, supra note _; Lemley, Taking Seriously, supra note _; Glynn S. Lunney, Jr., Copyright's Mercantilist Turn: Do We Need More Copyright or Less? (working paper 2012), available at http://ssrn.com/abstract=2158874. Some suggest that property rights are not regulatory. See, e.g., Thomas B. Nachbar, The Antitrust Constitution, 99 lowa L. Rev. 57, 70 (2013). But that presupposes a definition of property at some scale smaller than a market. A "property right" to prevent competition is in essence regulatory. 168 Ghosh, Decoding, supra note 
find a way to supply goods we thought would be provided only with government rule-making.

IP is no different in this respect than any other form of regulation. Regulation as a whole shouldn't disappear, but regulation of particular industries often turns out to be a reflexive response to a failure of imagination, something we do because we have done it for so long that we cannot imagine how a market in that industry could function without it.

We must similarly be willing to question IP in a post-scarcity economy. Changing economic characteristics may undermine the theoretical basis for IP. ${ }^{169}$ The Internet certainly undermines the logic of IP as an incentive to commercialize works once they are created. But it may also undermine the classic theory of IP as incentive to create. Once creation is cheap enough, people may do it without the need for any IP incentive. This suggests that we should pay more attention to alternative means of encouraging production, rather than assuming the superiority of IP. ${ }^{170} \mathrm{IP}$ will continue to exist in a post-scarcity economy, but it is likely to recede in importance as a driver of creation.

It is hard to translate this skepticism into immediate policy prescriptions, both because the whole point is that the need for IP will be sensitive to individual industry characteristics and because the technologies I am discussing are still in their infancy. Nonetheless, some general lessons from the Internet experience seem appropriate. First, we should resist the tendency to expand IP reflexively to meet every new technological challenge. Incumbent industries are

169 See John M. Newman, Copyright Freeconomics 66 Vand. L. Rev. 1409 (2013) ("when faced with the 'magic' of zero prices, the neoclassical economic model underpinning modern U.S. copyright law collapses. As a result, the shift to a freeconomic model raises fundamental questions that lie at the very heart of copyright law and theory.").

170 See Amy Kapczynski, The Cost of Price: Why and How to Get Beyond Intellectual Property Internalism, 59 UCLA L. Rev. 970 (2012); Daniel J. Hemel \& Lisa Larrimore Ouellette, Beyond the PatentsPrizes Debate, 92 Tex. L. Rev. 303 (2013); Michael Abramowicz, Perfecting Patent Prizes, 56 Vand. L. Rev. 115 (2003). For a more skeptical note, see Saul Levmore, The Impending iPrize Revolution in Intellectual Property Law, 93 B.U. L. Rev. 139 (2013). 
always threatened by new technologies and they often turn to regulation to create barriers to those technologies in order to protect the old way of doing thing. IP owners will do the same thing. Trademark owners used to a world in which only commercial counterfeiters reproduce their brands will struggle with how to adapt trademark law to private home generation of logoed products. ${ }^{171}$ But it is not clear that they should have a right to prevent the mere making of a thing that looks like a trademark when it is not sold in commerce. ${ }^{172}$ Some changes in the economics of production and distribution may call for IP rights as a response, but others may suggest that IP rights are unnecessary. ${ }^{173}$ And the post-scarcity technologies heighten the disconnect between what the law covers and what the public things as fair, because IP law will increasingly purport to govern what individuals do for noncommercial purposes in their own home. $^{174}$

Second, IP owners should not be allowed to reach beyond suing infringers and seek to shut down or modify the technology itself. The temptation for them to do so is powerful, and will only grow as new technologies democratize the acts of reproduction and distribution. But blocking technological development in order to protect IP rights is likely to do far more damage than good to the economy. We have (so far) avoided that route with the Internet, but the

171 See Desai \& Magliocca, supra note _, at 37.

172 For discussion, see Stacey L. Dogan \& Mark A. Lemley, The Merchandising Right: Fragile Theory or Fait Accompli, 54 Emory L.J. 461 (2005); Desai \& Magliocca, supra note _, at 41; Jeremy Sheff, Veblen Brands, 96 Minn. L. Rev. 769 (2012).

173 See Matthew Adam Susson, Watch the World "Burn": Copyright, Micropatent and the Emergence of 3D Printing 45 (working paper 2014), available at http://ssrn.com/abstract=2253109 (arguing that legislators should refrain from expanding IP protections in response to 3D printing until we see how the technology develops).

174 As Pam Samuelson put it in the context of the Internet, "[c]opyright has suddenly become significant not only to industry insiders who are steeped in this law's complexities, but also to the millions of people who access information on the Internet and who often share this information with others." Pamela Samuelson et al., The Copyright Principles Project: Directions for Reform, 25 Berkeley Tech. L.J. [draft at 2] (2011). 
expansive interpretation given doctrines of secondary liability in copyright makes it a continued risk. Patent law may pose an even greater risk, because intermediaries and technology developers could be liable for direct rather than contributory infringement, depending on the way the claims are drafted. ${ }^{175}$ IP laws should be reformed to give more breathing room to new technologies, even if those technologies can be misused for infringement. We may well need a form of legal immunity for the designer of the hardware for these technologies - 3D printers, gene assemblers, and open robots, just as we do for providers of general-purpose computers or Internet service providers. ${ }^{176}$ And we may also need immunity for those who host the information content that runs on that hardware. ${ }^{177}$ Like those technologies, the makers of 3D

175 For an argument that contributory rather than direct infringement liability is more likely, see Syzdek, supra note _, at 15-18.

176 Calo, Need, supra note _; Calo, Open Robotics, supra note _, at [draft at 136-138] (proposing such a regime for open robotics); Desai \& Magliocca, supra note _, at 46 (proposing such a regime for 3D printing); Linda Kahl, The Legal Infrastructure for Synthetic Biology, in Positioning Synthetic Biology to Meet the Challenges of the $21^{\text {st }}$ Century (Stephanie Joyce et al eds. 2013) (proposing such a regime for synthetic biology).

James Grimmelman suggests that the legal issues posed by 3D printing are "as hard as some of the most notoriously difficult parts of copyright - but [] also no harder." James Grimmelman, Indistinguishable from Magic: A Wizard's Guide to Copyright and 3D Printing, 71 Wash. \& Lee L. Rev. (forthcoming 2014). But 3D printing implicates not just copyright but also patent and design patent law, and the rules those laws have traditionally applied are different.

177 Desai \& Magliocca, supra note _, at 54-56. The Digital Millennium Copyright Act arguably protects those data host sites from copyright liability. But there is no corresponding safe harbor for patent or design patent infringement. See Mark A. Lemley, Rationalizing Internet Safe Harbors, 6 J. Telecomm. \& High Tech. L. 101 (2007). Whether a data host site is liable for patent infringement will therefore depend on whether making a copy of the blueprint or information can itself be "making" or "using" the invention. The answer will depend on how the claim is written. Software patent claims may well cover program code hosted on a computer even if that code is not operated on that computer. By contrast, at least one commentator has argued that copying a blueprint for 3D printed object is not "making" the object itself. Daniel Harris Brean, Asserting Patents to Combat Infringement via 3D Printing: It's No "Use,", 23 Fordham Intell. Prop., Med. \& Ent. L.J. 771 (2013). If so, 3D printer design host sites will face little risk of patent infringement. The direct infringer would be the individual printing the design; intermediaries will be liable for inducement only if they know that the design is infringing. See GlobalTech Appliances v. SEB S.A., 131 S.Ct. 2060 (2011). 
printers, gene assemblers, and open robots are building a substrate divorced from the

informational content of the design, and hence from the uses to which the device might be put.

Finally, IP law needs to make it easier for creators to opt out of the IP regime. ${ }^{178}$ The

Internet is littered with unnecessary copyrights automatically given to works that have no need

for them. While there are ways to release an idea to the public irrevocably, they are complex

and seldom used. ${ }^{179}$ It is easier not to obtain a patent or a design patent, but simply opting not to do so will not protect an inventor from being sued for sharing her own invention with the world. ${ }^{180}$ As a result, even inventors with no interest in asserting IP rights often feel the need to obtain their own for defensive purposes. IP law needs to protect inventors, not just by offering them exclusive rights, but by shielding them from exclusive rights claimed by others. ${ }^{181}$

\section{B. What Will a Post-Scarcity Economy Look Like?}

While the focus of this paper is on the role of IP in encouraging (or retarding) creation in the post-scarcity economy, it is worth ending with some thoughts on the broader implications

178 See von Hippel, Democratizing, supra note _, at 115-17.

179 See, e.g., Lior Jacob Strahilevitz, The Right to Abandon, 158 U. Pa. L. Rev. 355 (2010); Matthew W. Turetzky, Applying Copyright Abandonment in the Digital Age, 2010 Duke L. \& Tech. Rev. 19.

180 This is because patent and design patent law, unlike copyright law, do not require proof that the defendant copied the technology from the plaintiff. It is enough that the plaintiff has a patent whose claims cover what the defendant is doing. See supra note _. Cotropia and Lemley find that in some industries as many as $98 \%$ of all patent suits are filed not against copyists, but against independent inventors. Christopher Cotropia \& Mark A. Lemley, Copying in Patent Law, 87 N.C. L. Rev. 1421 (2009). 181 See Susson, supra note _, at 48 (making this argument). Cf. Clark D. Asay, A Case for the Public Domain, 74 Ohio St. L.J. 753 (2013) (arguing for legislation that makes it easier to opt out of IP altogether). Sam Vermont has suggested that patent law should include an independent invention defense. Samson Vermont, Independent Invention as a Defense to Patent Infringement, 105 Mich. L. Rev. 475 (2005). I have questioned whether that idea is appropriate as a general matter. Lemley, Proof of Copying, supra note _. But as more and more inventions occur in post-scarcity technologies, the case for an independent invention defense will grow stronger. 
of that new economy. It is not just IP law that is based on scarcity; our whole economy is.

What happens when most of the things people need and want are no longer scarce?

A number of commentators have begun to worry about this question. While getting things for free (or close to it) seems like a boon to the economy, they worry that salaries of most people in the country are based on jobs performing tasks that may soon be obsolete. ${ }^{182}$ If the Internet delivers our goods for us without trucks or stores, 3D printers manufacture our goods, gene assemblers take over a growing share of our health care and agribusiness, and robots provide many basic services, what is left for people to do? They could create the things machines will produce and deliver, but as I have suggested in this paper, that creation may not be accompanied by a healthy paycheck. Our productivity will continue to increase, but it will be machines, not people, that generate that additional productivity. ${ }^{183}$ If the returns to productivity accordingly accrue to capital, not labor, the result may be to deepen income inquality. ${ }^{184}$ Some worry about massive unemployment, the decline of the middle class professional, and exacerbating the growing gap between rich and poor. ${ }^{185}$ To the extent our economy is based on an ever-expanding spiral of consumption, a long-term drop in the cost of most goods could trigger a fundamental economic contraction. It could also trigger social

182 The number of people talking about this has gone from essentially zero a few years ago to legion today. See, e.g., Eric Brynjolfsson \& Andrew McAfee, Race Against The Machine: How the Digital Revolution is Accelerating Innovation, Driving Productivity, and Irreversibly Transforming Employment and the Economy (2013); Jon Evans, VCs on Equality, Unemployment, and Our Uncertain Future, TechCrunch, Feb. 15, 2014, available at http://techcrunch.com/2014/02/15/vcs-on-inequalityunemployment-and-our-uncertain-future/?utm campaign=fb\&ncid=fb; Coming to an Office, supra note _; David H. Autor \& David Dorn, How Technology Wrecks the Middle Class, N.Y. Times, Aug. 25, 2013, at 6; David Rotman, How Technology is Destroying Jobs, MIT Tech. Rev., June 12, 2013, available at http://www.technologyreview.com/featuredstory/515926/how-technology-is-destroying-jobs/. 183 Rotman, supra note _; Jeremy Rifkin, The End of Work (1995).

184 Thomas Piketty, Capital in the Twenty-first Century (2013).

185 Evans, supra note _; Autor \& Dorn, supra note _. 
unrest; work is central to human social identity, and in the past those displaced by technology have reacted violently against it. ${ }^{186}$ One might also worry about vesting more and more power in the companies that control the networks over which information flows, companies that face little competition and seem less and less likely to be subject to common-carrier regulation. ${ }^{187}$ And other aspects of our legal system, like torts, will have to change when the people who produce goods are no longer large companies who design them but the very individuals who might be injured by them. ${ }^{188}$

While the risks these commentators have identified are substantial, I am somewhat more optimistic than many who have thought about this issue. This is not the first time technology or market forces have fundamentally disrupted our economy. I was alive in a time when the United States was considered a leader in manufacturing, and making products employed a substantial share of our workforce. ${ }^{189}$ And I'm not that old. Today only $10 \%$ of our jobs come from manufacturing; the rest have been sent overseas or replaced by automation. ${ }^{190}$ The loss of manufacturing jobs created substantial disruption, but it did not destroy our economy or lead to a long-term increase in unemployment. Rather, it created transition issues

186 See, e.g., Thomas L. Friedman, If I Had a Hammer, N.Y. Times, Jan. 12, 2014, at 11 (discussing modern analogs to the 1830 s Luddite movement, in which the unemployed attacked factory machines that had displaced their jobs).

187 See, e.g., Kevin Werbach, The Battle for Marginal-Cost Connectivity, HuffPo, April 8, 2014, http://www.huffingtonpost.com/kevin-werbach/the-battle-for-marginalco b 5110512.html.

188 Law responds to risk either by regulating entry or by regulating consequences. Tort law has generally regulated consequences, but that seems less and less feasible in a world in which production is noncommercial and democratized. See Deven R. Desai, The New Steam: On Digitization,

Decentralization, and Disruption, __ Hastings L.J. _ (forthcoming 2014); Engstrom, supra note _. Entry regulation seems both likely ineffective and a bad idea even if it could work. Desai, supra. We may need to replace tort law with a social safety net as it becomes harder and harder to find those who make unsafe products and hold them liable.

189 Manufacturing represented $30 \%$ of all U.S. jobs in the 1950 s and 1960 s. Rotman, supra note _. 190 Id. 
for individual workers, but the workforce as a whole transitioned into service and technology jobs. ${ }^{191}$ Even industries still in transition, like the Internet, bring new opportunities along with disruption. A study by the McKinsey consulting group, for instance, found that the Internet has created nearly three times as many jobs as it has destroyed. ${ }^{192}$

Going further back, there was a time when over $70 \%$ of the people in the United States were primarily employed producing food. Even in 1900 the number was $41 \%$. Today that number is below $2 \%{ }^{193}$ That transition was the first real move to a post-scarcity economy. And it was a dramatic one, more dramatic than anything we face today. What would people do when they no longer needed to grow food to survive? The answer is instructive: they would do a whole array of things no one in 1800 had ever imagined, simply because they could. They were freed from the need to work to feed themselves and turned loose to create new things and new means of passing their time. The result was the Industrial Revolution, which brought dramatic change but also unprecedented improvement in the human condition. Post-scarcity technologies promise the same sorts of improvements, reducing the cost of material things, health care, and services and greatly expanding their availability. ${ }^{194}$ And they may provide those benefits while reducing the environmental footprint of consumption; the small bit of electricity it costs to download a song does far less harm to the world than manufacturing plastic discs, putting them in plastic cases, trucking them to retail stores and having people

191 Id. ("no historical pattern shows these shifts leading to a net decrease in jobs over an extended period.... [W]e have never run out of jobs. There is no long-term trend of eliminating work for people.").

192 See, e.g., Jacques Bughin et al., Internet Matters: The Net's Sweeping Impact on Growth, Jobs, and Prosperity, May 2011, available at http://www.mckinsey.com/insights/mgi/research/technology and innovation/internet?matters. 193 Rotman, supra note _.

194 See Peter Diamandis, Abundance: The Future is Better Than You Think (2012); Tyler Cowen, Who Will Prosper in the New World, N.Y. Times, Sept. 1, 2013, at 5. 
drive to the stores to buy and sell them. ${ }^{195}$ 3D printing and robotics may offer similar environmental benefits.

What will people do when they no longer have to work to produce the goods and services they need and want? I don't know. But I am doubtful the answer is "nothing." John Maynard Keynes predicted in 1932 that increases in productivity would mean that people would only work fifteen hours a week; there was simply no need to work more than that to pay for necessities. ${ }^{196}$ It didn't happen - not because the productivity increases didn't materialize, but because there is something inherent in us that drives us to compete. We may make that competition artificial, as Barton Beebe has argued trademark law does. ${ }^{197}$ We may direct it in socially useful ways, rewarding people in social "markets" for contributing to the world in positive ways. ${ }^{198}$ Or, most likely, we will devote our time to doing, consuming, and making things that none of us can imagine today. As Lawrence Katz puts it, "[p]eople have always been able to create new jobs. People come up with new things to do."199

Notably, though, they will not necessarily do it within the framework of a scarcity-based economics driven by price. The economy we have known for over a century may play a smaller and smaller role in defining how people actually live their lives. As Jeremy Rifkin puts it:

195 See generally Rifkin, supra note _, at 92 (discussing how 3D printing can change our use of the transportation network).

196 John Maynard Keynes, Economic Possibilities for Our Grandchildren, in Essays in Persuasion 358, 369 (1932).

197 Barton Beebe, Intellectual Property Law and the Sumptuary Code, 123 Harv. L. Rev. 809 (2010) (arguing that trademark law creates scarcity in luxury goods in order to protect relative status, even though that scarcity is artificial; knock-off purses are often of equal quality to their brand-name counterparts).

198 Katya Assaf, Trademarks and Social Competition (working paper 2014) (arguing for an economy of good deeds).

199 Rotman, supra note _ (quoting Katz); Rifkin, supra note _, at 266-67. 
As more and more of the goods and services that make up the economic life of society edge toward near zero marginal cost and become almost free, the capitalist market will continue to shrink into more narrow niches where profitmaking enterprises survive only at the edges of the economy. ${ }^{200}$

...

We have been so convinced of the economics of scarcity that we can hardly believe that an economy of abundance is possible. But it is. ${ }^{201}$

We may spend more of our time inventing and creating, not because we are paid to do so but simply because we have that time to spend. Post-scarcity technologies give more of us the means to be more creative. They give us an abundant source of raw materials to play with, mix, and remix. ${ }^{202}$ And they free us from constraints that demand our time and our attention. ${ }^{203}$ And that, more than any legal regime designed to encourage creativity, makes me optimistic for the future.

\section{Conclusion}

The Internet is a harbinger of things to come - of a raft of new technologies that offer the promise of separating creativity from production and distribution, and reducing the cost of all three. Those technologies challenge the basis for our IP system, and indeed the basis for our economy as a whole. The lessons from the Internet experience are surprising and encouraging: people will create when given the opportunity to do so, even without effective IP protection. Those lessons will have relevance for patent and design patent as well as copyright as postscarcity technologies remake more and more of our economy in the shape of the Internet.

200 Rifkin, supra note _, at 5.

201 Id. at 150.

202 See, e.g., Lawrence Lessig, Remix: Making Art and Commerce Thrive in the Hybrid Economy (2008).

203 See Sendhil Mullainathan \& Eldar Shafir, Scarcity: Why Having Too Little Means So Much 3-7(2013) (arguing that scarcity not only requires time to satisfy, but it directs the mind towards the scarce thing at the expense of more productive lines of inquiry). 
The prospect of that reshaping has caused many to worry about the death of the middle class and the collapse of an economy based on a scarcity that will no longer exist. The disruptions we face are real, and I don't have a good answer to what people will spend their time doing over the next century or how (or even if) they will get paid. But I think history gives us reasons to be optimistic. Thinking about such questions has been the province of science fiction authors, ${ }^{204}$ but understanding what a post-scarcity economy will look like is the great task of economics for the next century.

204 Neal Stephenson, The Diamond Age; Cory Doctorow, Down and Out in the Magic Kingdom. 